\author{
University of Texas Rio Grande Valley \\ ScholarWorks @ UTRGV
}

\title{
Trading Income and Bank Charter Value during the Financial Crisis: Does Derivatives Dealer Designation Matter?
}

\author{
Peter V. Egly \\ The University of Texas Rio Grande Valley, peter.egly@utrgv.edu \\ Jun Sun \\ The University of Texas Rio Grande Valley, jun.sun@utrgv.edu
}

Follow this and additional works at: https://scholarworks.utrgv.edu/ef_fac

Part of the Finance Commons

\section{Recommended Citation}

Egly, P. V., \& Sun, J. (2014). Trading income and bank charter value during the financial crisis: Does derivatives dealer designation matter? The Quarterly Review of Economics and Finance, 54(3), 355-370. https://doi.org/10.1016/j.qref.2014.04.001

This Article is brought to you for free and open access by the Robert C. Vackar College of Business \& Entrepreneurship at ScholarWorks @ UTRGV. It has been accepted for inclusion in Economics and Finance Faculty Publications and Presentations by an authorized administrator of ScholarWorks @ UTRGV. For more information, please contact justin.white@utrgv.edu, william.flores01@utrgv.edu. 
Trading Income and Bank Charter Value during the Financial Crisis: Does Derivatives Dealer Designation Matter?

Peter V. Egly

Department of Economics and Finance

University of Texas - Pan American

1201 W. University Dr.

Edinburg, TX 78539-2999, USA

E-mail: pvegly@utpa.edu

Tel: +1-956-459-3514 and fax: +1-956-548-6392

Jun Sun*

Department of Computer Information Systems

and Quantitative Methods

University of Texas - Pan American

$1201 \mathrm{~W}$. University Dr.

Edinburg, TX 78539-2999, USA

E-mail: jsun@utpa.edu

Tel.: +1-956-665-2850 and fax: +1-956-665-3367

\begin{abstract}
Derivative markets have exploded over the last decade, remained active in the midst of the 2007-2009 financial crises and continue to be dominated by a small group of bank holding companies (BHC). BHC motives for derivative usage are usually tied to hedging purposes (balance sheet risk management), trading purposes (profit motives) or some combination thereof. This paper examines the relationship between derivative trading income and bank charter value for 27 BHC between 2001Q1-2011Q3. We find that the impact of derivative trading income on bank charter value, using Tobin's Q, is very small and seems to be tied to BHCs derivatives dealer trading designation. We also find that trading incomes are a modest fraction of net operating revenue, highly volatile, and did not contribute to overall $\mathrm{BHC}$ income during the crisis.
\end{abstract}

JEL Classification Numbers: F30, G21.

Keywords: Bank Holding Companies, Bank Charter Value, Derivatives

*Corresponding Author. Tel.:+1-956-665-2850; fax:+1-956-665-3367 E-mail address jsun@utpa.edu 
Trading Income and Bank Charter Value during the Financial Crisis:

Does Derivatives Dealer Designation Matter?

\section{Introduction}

In the banking industry, managers are tasked with a dual objective of managing the various sources of risk inherent in their business while maximizing shareholder value. Bank managers must balance between these objectives since increases in shareholder returns usually come at a cost of increased risk. Over the last few decades, we have witnessed rising popularity in the bank use of derivatives to manage various forms of risk they are exposed to including interest rate, foreign exchange and credit risk. A derivatives security is commonly defined as a financial security whose payoff is tied to (or derived from) a previously issued security. Derivative securities (e.g. swaps, futures, forwards, option contracts, among others) generally involves an agreement between two parties to exchange a standard quantity of an asset or cash flow at a predetermined price and an agreed upon future date. Thus, derivatives involve the buying and selling, or transfer of risk.

According to Sinkey and Carter (2000), banks participate in the derivatives market as dealers, end users or both. They also state that as end users, banks can use derivatives either to hedge against unexpected changes interest rates, foreign exchange rates, or commodity prices or to speculate on the future movement of these economic variables. These authors also note that only the largest banks act as dealers by providing over- thecounter (OTC) derivative products to nonfinancial firms and other banks. It is also well documented that derivative activities are centered in a handful of large banks. Per the 2011Q4 bank trading and derivatives activities report prepared by Office the Comptroller 
of the Currency (OCC), there are five large commercial banks that account for $96 \%$ of all banking industry notional amounts of derivatives while $99 \%$ of the total is held by the top 25 banks. The industry concentration among the dealer banks as measured by the Herfindahl Index had remained well above the 30\% level between 2001Q4 and 2008Q4, and since 2011Q4 has settled modestly below the 25\% level as seen in Figure 1. Conventional wisdom suggests that higher levels of industry concentration allow for monopolist behavior which is a source of market power that may favorably impact a bank's charter value.

The potential for significant fee income generation has led banks to participate in derivative markets to offer risk management services to its corporate clients. This trend has grown over the last few decades with fees incomes representing an important revenue source to help offset flat to declining spreads earned on traditional lending business. It is clear that a select group of large banks, namely those that focus on derivative activities, earn far more fee income than those banks that are not set up to participate in the derivatives market. It is also known that dealing and trading in derivative products through a bank profit center requires substantial investment in financial, human, intellectual and reputational capital. The substantial required capital investment poses a barrier to entry into the derivative market making activity for the smaller banks

Some researchers claim that off-balance-activities, including derivatives trading, have become a potential source of bank charter value for the large banks (e.g. Furlong and Kwan, 2006). Derivative trading not only generates important fee income to the banks but provides opportunities for bankers to add value through cross-selling opportunities and enhanced customer relationships. Based on the implied negative 
relationship between risk and charter value, derivative activities used for hedging purposes should favorably impact bank charter value. Prior to the financial crisis, Brunnermeier et al. (2012) state that banks have increasingly earned a higher proportion of their profits from non-interest income (including income from derivatives trading) compared to interest income. Therefore, it would seem interesting to explore the linkage between derivative dealer bank behavior and charter value. The term charter value is broadly defined as the expected present value of a firm's economic rents. In a banking context, Palia and Porter (2004) refer to charter value as the present value of the bank's future economic profits as a going concern. The bank's profit potential in turn is highly linked to customer relationships, efficiency and market power. Through the issuance of an approved bank charter, banks have the ability to operate in a regulatory environment that may curtail external competition from non-bank sources. Banking legislation that curbs such competition from non-bank sources provides market power to approved banks thereby creating value.

The continued evolution in derivative securities, and the significant trading losses recorded during the 2007-2009 financial crises, has drawn attention to bank regulators, law makers and the investor public. For our sample of 27 bank holding companies (BHC), aggregate trading losses from 2007Q3 to 2008Q4 totaled U.S. $\$ 73.6$ billion ${ }^{1}$. The collapse of the largest investment banks who were the market makers of traded securities, the originators of new securities, and producers of derivative products also placed the

\footnotetext{
${ }^{1}$ The quarterly trading losses reported during the crisis period by our sample BHCs are in sharp contrast with the cumulative trading incomes reported during the rise of the housing boom period. From 2003Q3-2004Q4, cumulative trading incomes for our BHC sample totaled U.S. \$50.1billion. Over the full sample period, aggregate trading incomes were reported in 37 of the 43 quarters resulting in U.S. \$506.9 billion in cumulative trading income. More recently, the WSJ May 11, 2012 article “J.P. Morgan’s \$2 Billion Blunder" by Fitzpatrick, Zuckerman and Rappaport reported on the large trading losses posted by the bank during 2012Q2 resulting from bad investment decisions made on credit default swaps (CDS) by the bank's risk management group.
} 
derivative markets in the spotlight. The severity of bank losses reported during the 20072009 financial crisis, including losses from proprietary trading that involved derivative activities, ultimately led to the Dodd Frank Act of 2010 that contains the Volker Rule. From a broad perspective, the attention to the use of derivatives by banks is further attributed to the dramatic increase in the gross notional value of derivatives that far exceed the increase in BHC assets as depicted in Figure 2. It is important to examine the large dealer banks since Brunnermeier et al. (2012) point out that systemic risk is higher for banks with higher non-interest income ${ }^{2}$ to interest income ratios, a condition that is common with large dealer banks. They suggest that activities that are not traditionally linked with banks such as deposit taking and lending are associated with a larger contribution to systemic risk.

This study investigates the following research questions: 1) Does trading income contribute to BHC charter value? 2) Does derivatives dealer designation change the impact of trading incomes on BHC charter value? and 3) Did trading incomes help support BHC net operating revenues during the 2007-2009 financial crises? This research is important since substantial derivative exposure with respect to BHC assets and capital can lead to disruptive consequences in the event of unfavorable market movements or increases in counterparty risk. Failure by a large complex financial institution, such as those included in our sample, may produce spillover effects across the financial system which could lead to negative repercussions on the economy and the business community. The timeliness of the research is appropriate given the fragility of the U.S. economy that

\footnotetext{
${ }^{2}$ Brunnermeier et al. (2012) decompose non-interest income into two components: 1) trading income and 2) investment banking and venture capital income. They find that both components are approximately equally related to systemic risk. They also find that banks with higher trading income one-year prior to the recession earned lower returns during the recession period and that no such significant effect was found for the investment banking and venture capital income variable.
} 
is currently showing weak signs of mild recovery. This research is also germane to bank regulators who examine and monitor the complex relationships between the degree of BHC market power, cost and profit efficiency measures and overall bank stability. An improved understanding of the connection between derivative activity and BHC charter value expands market based discipline measures used by uninsured depositors and investors to punish (or reward) banks for excessive (or prudent) risk taking activities.

This study contributes to the literature in the following interesting way. First, we do not identify any published study that explicitly examines the contribution of trading income to BHC charter value. This issue is important given the accelerated growth in derivative activity during the first decade in the new millennium and the volatility that trading incomes exhibit over our sample period as shown in Figure 3 while acknowledging that the bulk of such incomes are predominately generated by dealer banks. This study attempts to bridge the gap in the current literature on charter value and derivative activity. Second, we examine data from 2001Q1 to 2011Q3 that covers periods of economic expansion (including the build up of the housing bubble) and the subsequent bust. We also cover a greater time span of the latest U.S. financial crisis. The sample time frame covers changes in economic climate and periods of significant derivative usage that should allow for improved inferences to be made on the effects of derivative usage on BHC charter value. Lastly, this study contributes to the body of literature that suggests that derivative activity is driven by profit as opposed to hedging motives. This study implies that BHCs increase risk through their off-balance sheet activities that generate volatile trading revenues. Any contribution of trading revenues to $\mathrm{BHC}$ charter value is suspect at best due to their volatility and given the fact that they account for such a small 
fraction of BHC's net operating revenues.

The primary finding of this study is that trading income has a negative impact on BHC charter value yet the impact becomes positive when trading income is interacted with derivative dealer designation. Trading income's contribution to BHC charter value is damped by the fact that trading income is only a small fraction of BHCs' net operating revenue and is highly volatile. Finally, we observe that trading income did not contribute to overall $\mathrm{BHC}$ income during the financial crisis.

This study is organized as follows: Section 2 presents the literature review and includes some discussion on bank charter value. Section 3 puts forth research hypotheses. Section 4 describes the data and defines the variables used in the study. Section 5 introduces the methodology and Section 6 discusses the results, followed by the conclusion.

\section{Literature Review}

\subsection{Derivative Literature}

The latest derivative literature seems to be motivated by the impetus, and product innovation, in derivative markets over the last few decades and more recently by the episodes of large trading losses, including those generated during the latest U.S. financial crisis. These events have heightened public investors' interest regarding the role of banking institutions in derivative markets (see Purnanandam (2007), Ashraf et al. (2007) Minton et al. (2009), Zhao and Moser (2009) and $\mathrm{Li} \& \mathrm{Yu}$ (2010), among others). There is an ongoing debate regarding the impact of derivative usage on bank's risk. Purnanandam (2007) jointly model bank failure probability and hedging decisions using a two stage estimation technique that is applied to data on U.S. commercial banks from 1997Q4 through 2003Q3. This author's findings are in line with hedging 
theories in that banks with higher probabilities of financial distress manage their interest rate risks more aggressively through on-balance sheet and off-balance sheet instruments. Zhao and Moser (2009) simultaneously model two alternative methods of interest rate risk management (i.e. maturity gap analysis and interest rate derivative usage) on a sample of publicly traded BHC during 1998-2003. They conclude that BHCs employ gap analysis to manage exposure to changes in short term interest rates and use derivatives to manage residual rate exposures resulting from changes in the slope of the term structure of interest rates. Their results support the view that interest rate derivative usage has risk reducing effects. During the 2007-2009 financial crises, Duffie (2010) explains that dealer banks are exposed to new forms of bank runs and describes the mechanics by which dealer banks can fail which include: (i) the flight of prime-brokerage clients, (ii) the loss of short-term secured credit, (iii) defensive reactions of derivatives counterparties and (iv) loss of cash and securities settlement privileges at clearing banks.

The derivative literature has been extended in recent years to investigate credit derivatives that according to some observers are claimed to be a revolutionary financial innovation that allows banks to manage credit risk apart from other forms of financial risk such as interest rate and exchange rate risks. Using annual data from 1997 through 2004 on a sample of 346 BHCs in the U.S., Ashraf et al. (2007) find that the participation in credit derivative markets is closely related to bank size whereas there is limited evidence that entry barriers related to franchise value or prior experience in derivative markets are important. Examining credit derivative activities by large U.S. bank holding companies (BHC) from 1999-2005, Minton et al. (2009) find that only a small fraction use credit derivatives and that most of their positions are held for dealer activities rather than for loan hedging purposes. A theoretical paper by Instefjord (2005) 
that focuses on risk and hedging through credit derivatives using a model based on costs of financial distress proposes two effects of credit derivatives innovation. The author concludes that credit derivatives enhance risk sharing that supports a hedging argument. However, the author also suggests that credit derivatives make further acquisition of risk more attractive. The implication is that if the second effect dominates the first, then credit derivative activity could destabilize the banking sector.

Derivatives markets dealing with foreign currency claims and the expanded scope of derivative activities into international markets have also been also been subject of research. For example, Chaudhry et al. (2000) investigates the relationship between market based risk measures and foreign currency claims using a three factor model on a sample of 112 U.S. publicly traded BHC's using data from 1989 through 1993. The results suggest that options tend to increase bank risk, swaps are used mainly for hedging purposes, and that forward contracts and currency commitments have only a minor impact on bank risk. The work of Chaudhry et al. (2000) was extended to an international setting by Reichert and Shyu (2003). These authors using multifactor index models and applying VaR analysis on bank equity find similar results to those reported by of Chaudhry et al. (2000). The results in Reichert and Shyu (2003) are the strongest and most consistent for the sample of U.S. dealer banks. Weaker results were obtained for the European banks and the Japanese banks, respectively.

In sum, the relevant literature deals mostly with how derivative usage impacts bank risk and examines the underlying motives for derivative activity- i.e. end users (mainly for hedging purposes) vs. dealers (profit driven market making). The research does not offer clear answers as to which of these two underlying motives is most likely to prevail. Furthermore, little attention has been given to the effects of derivative usage on bank revenue and or on bank performance. 
We find one example in Li \& Yu (2010). These authors examine the impact of derivative usage on bank performance, proxied by return on assets (ROA), and on BHC risk, captured through the asset volatility. Applying panel data techniques to a sample of 18 large U.S. BHC between 2005Q2 and 2008Q3, these authors find that derivative activities increased BHC overall risk level since BHCs were able to take on more speculative positions in derivative contracts. These authors also find that speculative derivative positions were eventually rolled down after the subprime mortgage loan crisis.

\subsection{Bank Charter Value}

Charter value has commonly been defined in terms of a bank's future economic profits, generated as a going concern, that are discounted at a market required rate of return. Banks, for example, are able to earn economic profits by attracting funds at below-market rates (e.g. FDIC insured demand deposits) or setting loan yields at above market rates. Under these conditions that suggest a form of pricing power, bank's assets (liabilities) may be valued at above (below) their respective book values. Historically, U.S. banks derived charter value from market power awarded to them through government regulations that curbed interbank and nonbank firm competition i.e. geographic and product based sources of market power. The literature has put forth other banking activities outside of traditional lending and deposit taking functions that potentially impact charter value. One such potential source comes from off-balance sheet activities, which is the subject of our study. Finally the literature suggests that improved bank operational efficiencies and changes in business cycle conditions may also influence bank charter value - see Furlong and Kwan (2006).

Jones et al. (2011) explains that although charter value may not be directly observed, theory suggest that Tobin's Q should be a useful proxy. These authors also formulate the relationship 
between Tobin's Q and charter value in the following fashion. For publicly traded banks, Tobin's Q is defined as the market value of the bank's assets (i.e. market value of bank equity plus its debt) divided by the replacement cost of the bank's assets. Therefore, Tobin's Q may be expresses as:

Tobin's $Q=\frac{M V E+B V L}{B V A}$

Where $M V E$ is the market value of equity, $B V L$ is the book value of liabilities and $B V A$ is the book value of assets. It is noted that if all assets and liabilities were recorded at their historical cost and if the markets consistently valued banks correctly, then the relationship between market value of equity, book value of equity and charter value could be expresses as:

$M V E=B V E+C V$ where $C V$ represents the bank's charter value.

The market value of equity $M V E$ by definition is the present value of the banks expected income stream discounted by the risk-adjusted rate of return required by the market $r_{m}$. The expected income stream for Bank $i$ can be separated into two components: expected normal profits $N P$ and expected economic profits $E P$. On this basis, the market value of bank equity may be written as:

$$
M V E_{i}=\sum_{t=0}^{\infty} \frac{N P_{i t}+E P_{i t}}{\left(1+r_{m}\right)^{t}}
$$

In a perfectly competitive economy, all profits are competed away so that the existing shareholders earn just the required market rate of return on their capital that they supply to the bank. On this basis, Jones et al. (2011) suggests that the discounted stream of normal profits NP, which are those earned in a perfectly competitive economy, will equal the book value of equity since the market values of perfectly competitive financial assets and liabilities will equal their respective book values. In the case where a bank can earn above-normal profits (i.e. expected economic profits) on its capital, the present value of the future stream of cash flows will accrue to the benefit of the stockholders. Under this condition, assets and or (liabilities) are valued by 
the market above (below) their respective book values and the stream of economic profits discounted at the required market rate of return will equal the bank's charter value. By substituting equation 2 into equation 1 we come up with the following equation:

$\operatorname{Tobin}^{\prime} \mathrm{s} Q \cong \frac{B V E+C V+B V L}{B V A} \cong 1+\frac{C V}{B V A}$

Equation 4 shows us the relationship between Tobin's Q and charter value. We note that Tobin's Q is a scaled measure of charter value. As pointed out by Jones et al. (2011), the Tobin's Q measure can be a misleading measure of charter value if the market fails to properly value the bank. For example, market misalignments with respect to fundamental values usually occur during periods of stock market bubbles or stock market crashes. If the market fails to sufficiently discount assets for risk (in part due to the opaque nature of banks), then Tobin's Q increases while the high-risk assets earn substantial profits. However, Tobin's Q falls sharply once the risk becomes apparent and the market valuation of assets decline accordingly.

\section{Research Hypotheses}

This paper introduces two testable hypotheses dealing with the impact of trading incomes on bank charter value. Furlong and Kwan (2006) find that, with the exception of the very largest $\mathrm{BHC}$, the market is less confident about the reliance on activities generating non-interest income, including derivatives trading, relative to other banking activities. Furthermore, while trading incomes on balance have been positive over our sample period 2001Q1-2011Q3, they represent only a modest fraction of net operating incomes, are highly volatile and did not contribute to overall BHC income during the crisis. According to Stiroh (2004), high volatility in trading incomes led banks to undertake higher risk that resulted in lower risk-adjusted profits. We also accept from Jones et al. (2011) that there is an implied negative relationship between risk and 
charter value. On this basis, trading incomes would not appear to be a contributing factor to bank charter value. This rationalization leads to the first hypothesis:

$\mathrm{H}_{1}$ : There is an inverse relationship between trading derivative incomes scaled by the sum of net interest and non-interest income and bank charter value.

It is well documented that most derivative market making activity is generated by a few large BCHs that dominate the market. Furlong and Kwan (2006) further note that the mix of activities that generate non-interest income differs based on BHC size and that for the larger BHCs the mix of income is weighted towards market making derivatives activities. The concentration in derivative activity among few large $\mathrm{BCHs}$ has been explained by the requirements of substantial investment in financial, human and intellectual capital that along with advance internal controls and favorable trading reputation are necessary to deal in derivative markets. Furthermore, since it is plausible that charter value is related to industry concentration and that industry concentration is greater for dealer banks compared to smaller commercial banks in general, we would expect that trading by dealer banks may have a positive impact on bank charter value. To the extent that trading incomes are associated with trading exposures taken by BHC that are providing dealer (marking-making) services to customers, trading exposures do not add to BHC risk. On the other hand, proprietary trading by BHC would introduce an element of risk. The large dealer banks that engage in proprietary trading typically have access to a broader scope of funding sources and usually exhibit favorable capitalization characteristics, compared to their medium and small counterparts that allow the large dealer banks to afford higher risk. We suggest that the largest dealer banks can benefit from trading activity. This leads to the second hypothesis:

$\mathrm{H}_{2}$ : There is a direct relationship between trading derivative incomes by dealer banks scaled by the sum of net interest and non-interest income and bank charter value. 


\section{Data}

\subsection{Sample and Sources}

To develop our sample in the first stage we search the list of the top 50 bank holding companies (BHC) as of 2011Q3 as reported by the Federal Financial Institutions Examination Council (FFIEC). Privately held BHCs are excluded from the final sample since our analysis includes a Tobin's Q measure that uses stock price data. We also exclude from our sample those companies that have marginal, if any, focus on traditional banking activities (i.e. insurance companies, credit card companies, pure investment banks).To be included in the final sample, we require that the companies have some level of derivative activity. Applying the above sample selection criteria we identify 18 BHCs for our study. In an effort to expand the sample size, in the final stage we relax our selection criteria only to the extent that BHCs are no longer required to be included in the list of the top $50 \mathrm{BHC}$ which allows to consider smaller BHCs in terms of asset size and derivative exposure which brings us to our final sample of 27 BHCs. We collect balance sheet, income statement and derivative data for 27 bank holding companies (BHC) over the sample time period 2001Q1 to 2011Q3 ${ }^{3}$. Given the focus of this study and the high concentration of derivative usage by a small group of large BHCs as confirmed by our Herfindahl index measure that is graphed in Figure 1, we believe that we have an adequate representative sample that includes a good mix of BHC based on asset size, structure, business activities and business scope ${ }^{4}$. A visual inspection of Figure 2 that

\footnotetext{
${ }^{3}$ Although data is available prior to 2001Q1 which would expand the time horizon of this study, we believe that the time frame we chose is adequate since it covers periods of economic expansion (including the buildup of the housing bubble), the subsequent bust and a full time span of the latest U.S financial crisis. The time span in this study covers interesting trends in derivative market industry concentration that over the entire time period remains high (see Figure 1).

${ }^{4}$ The sample includes 3 of the top 5 derivatives users that collectively account for $96 \%$ of the total banking industry notional value of derivatives per the 2011Q3 OCCs bank trading and derivatives activity report. Roughly half of the
} 
presents an overlay of our sample that covers the period from 2001Q1 to 2011Q3 against the entire population of financial institutions that engaged in derivative activity between 1998Q4 to 2012Q4 also seems to support our sample selection. We reach a similar conclusion regarding the representative nature of our sample when we inspect Figure 3 that depicts the trading revenues (scaled by the sum of non-interest income and net interest income) for the banks in our sample, and Figure 4 that depicts those (unscaled) for insured U.S. commercial banks, with the latter covering a longer time span from 1997Q1 to 2012Q4 ${ }^{5}$. Appendix A contains the list of BHCs used in this study and the respective total assets and total notional value of derivatives for each $\mathrm{BHC}$ as of the end of sample period. The bank holding company information is extracted from Consolidated Financial Statements for Bank Holding Companies (call report form FR Y-9C) that are submitted on a quarterly basis to the Federal Reserve. The data from call reports that BHCs file are available through the Federal Reserve Bank of Chicago data base at the following website https://www.chicagofed.org/applications/bhc_data/bhcdata_index.cfm last accessed on 9/20/12. The BHC balance information used in this study includes total assets, total loans, real estate loans, total liabilities, various deposit measures (e.g. interest bearing and non-interest bearing deposits, money market savings accounts and small time deposits $<\$ 100,000)$ and a Tier 1 risk based capital ratio. The $\mathrm{BHC}$ income statement information consists of net interest income, non-interest income, total non interest expense, and trading revenue. The derivative information measures the gross notional value of derivatives broken down by contract type (i.e. interest rates, foreign exchange,

BHCs in the sample are identified on the list of the top 25 BHCs engaged in derivative activities per the previously referenced derivatives activity OCC report.

${ }^{5}$ Following the suggestion of an anonymous reviewer, in Figure 3 the trading revenue series (which are scaled by the sum of net interest income and non-interest income) represent an asset weighted mean to control for the wide dispersion that exists at the right tail of the bank-size distribution. We thank the reviewer for this suggestion. 
commodities and equities) and by purpose (i.e. derivatives held for trading vs. nontrading). Appendix B contains a list of the BHC variables used in this study and their respective code names as identified in the Federal Reserve Bank of Chicago data base.

\subsection{Descriptives}

Table 1 panels A through $\mathrm{C}$ provides summary descriptive information on BHC variables for the full sample and subsamples of BHCs based on derivatives dealer designation. Following Sinkey and Carter (2000), we classify those BHCs that are members of the International Swaps and Derivatives Association (ISDA) as dealers. These authors assert that dealer banks are not only involved as end users of derivatives but are also heavily active as dealers of over-the-counter (OTC) derivative products ${ }^{6}$.

Panel A suggests that we have a good mix of BHCs in our sample in terms of asset size, albeit with some skewness, with a mean (median) of U.S. \$260.6 billion (U.S. $\$ 64.7$ billion) ranging in size from a low of U.S $\$ 6.2$ billion to a high of U.S. $\$ 2.370$ trillion over the entire sample period. Trading derivatives, scaled by assets, seem to play a larger role in BHC activities compared to non-traded derivatives as the mean of scaled trading derivatives is roughly sixteen times larger than the mean of scaled non-traded derivatives. However, it is noted that trading derivatives exhibits greater volatility contrasted with the non-traded derivatives as seen in the large differences in standard deviations between these two asset classes (i.e. $875.94 \%$ versus $27.15 \%$ ). Trading derivative income is also volatile, based on reported standard deviation of $6.07 \%$, and represents only a modest fraction of BHC net operating revenues over the sample period as seen by the mean and (median) values of $3.09 \%(1.32 \%)$ respectively. On an operating

\footnotetext{
${ }^{6}$ The sample includes 8 derivative dealers that are identified through the ISDA. They are: JP Morgan Chase \& Co, Bank of America Corporation, Citigroup, Wellsfargo \& Co., State Street Corporation, Regions Financial Corp, PNC Financial Services Group Inc and Key Corp.
} 
basis, the BHC in the sample appear profitable, on average, over the sample period as measured by the mean (median) net-interest income values scaled by total average assets of $1.90 \%(1.75 \%)$ respectively. Real estate portfolios and core deposits are important components of BHC balance sheets with reported mean values, scaled by total assets, similar to those documented in related empirical studies that examine bank charter value (e.g. Jones et al., 2011; Furlong and Kwan, 2006).

The stark contrast between derivative dealers and non-dealers on several characteristics is reflected in Panels B and C of Table 1. Even though there are marked differences in terms of asset size between both groups, they exhibit similar attributes in terms of net interest income and overall operating efficiency. While trading derivatives and the related derivative incomes are greater for the derivative dealers compared to their counterparts, the variability on both measures is smaller for the derivative dealers given the respective coefficients of variation of 1.28 and 1.69 versus 1.94 and 2.08 respectively. Dealer banks have reduced reliance on core deposits for funding purposes, greater exposure on non-traded derivatives and smaller real estate loan exposures compared to non-dealer banks.

Table 2 reflects summary data on the quarterly growth rate of assets, trading income and derivatives for the full sample (Panel A) and the two bank groups (Panel BDerivative Dealer and Panel C- Non Dealers). To control for firm dynamics, particularly resulting from mergers and acquisitions, we exclude bank-quarter data with asset growth over the preceding quarter in excess of 50\%. Due to the potential impact that mergers and acquisitions may have on derivative activities, we also adjust trading income and trading derivative bank-quarter data accordingly. Over the sample period 2001Q1 to 2011Q3, 
asset growth was slightly higher on average for the dealer banks compared to the nondealer banks while the former also exhibited greater growth and lower volatility from trading incomes compared to the non-dealer banks. Table 2 also shows that while nondealer banks had higher growth in trading derivatives compared to the dealer banks they also experienced greater variability. As of the end of sample period 2011Q3, both bank groups, in spite of there vast size difference, exhibited strong capitalization slightly in favor of the dealer banks (average Tier 1 capital ratio of 13.206 vs. 12.919).

Table 3 shows contemporaneous bivariate correlations for the independent variables included in the model. With the exception of the correlations between trading derivatives and dealer designation with $\mathrm{BHC}$ total assets, all other correlations are either small or modest. The significant correlation between trading derivatives and dealer designation with BHC total assets is not surprising since dealers hold the largest trading derivative portfolios and are typically the largest banks. The small to modest correlations reported in Table 3 help mitigate any potential collinearity issues that could impact the model.

\section{Methodology}

Given the cross-sectional and time series dimensions of the bank sample data, we employ a panel data fixed-effects estimator to examine the effect of trading income and dealer designation on bank charter value proxied by Tobin's $Q$. The advantage of the fixed-effects estimation is that it allows for the cross-sectional units' (individual banks) time invariant unobserved effects to be correlated with the explanatory variables. While we are dealing with a relatively small bank sample, we believe that there are sufficient differences between the banks in terms of size and scope that would prevent us from proposing a pooled-cross section regression specification. The model includes trading 
income $^{7}$ as the primary variable of interest along with various bank control variables commonly used in the charter value literature (cf. Keeley, 1990; De Nicolo, 2001; Jones et al., 2011; Furlong and Kwan, 2006).

The BHC total asset variable controls for the effect of size on Tobin's Q and to control for the potential that the relative option value of the federal deposit insurance safety net increases with bank size as suggested by Furlong and Kwan (2006). In general, higher charter values are associated with BHCs that exhibit higher capital ratios under the so-called charter value hypothesis however larger BHCs tend to have lower capital ratios compared to smaller BHCs. As charter value begins to decline, the incentive increases for a BHC to take on added risk and abuse the deposit insurance option. On this basis, we expect a negative relationship between assets and charter value.

The net interest income and core deposits variables are well known proxies of market power that are widely used in bank charter value modeling. On this basis, we would expect that the market power derived from the aforementioned operating measures (i.e. net interest income and core deposits) is directly related to Tobin's Q. The inclusion of a loan variable is common in the bank charter value literature given that banks expect to earn rents from their lending activities and thus we expect a positive relationship between our loan variable and Tobin's Q. In most cases, real estate loans tend to account for the bulk of bank's total lending portfolio, which explains why we choose this lending variable in our specifications. Support for the efficiency variable is found in empirical

\footnotetext{
${ }^{7}$ Trading income captures the net gain or loss from trading cash instruments, off-balance sheet derivative contracts and sales of assets and other financial instruments. This line item also includes revaluations to carrying values of trading assets and liabilities resulting from marking to market adjustments as well as revaluations related to marking to market adjustments of interest rate, foreign exchange, equity, and commodity derivative contracts held for trading purposes. $\mathrm{Li}$ and $\mathrm{Yu}$ (2010) explain that the income from derivatives trading accounts for a large portion of BHC's trading income.
} 
studies by Berger (2003), Furlong and Kwan (2006) and Turk-Ariss (2010). Efficiency can be viewed as a potential source of bank charter value in light of emerging technologies in processing information and managing risk. Berger (2003) explains that given the information based nature of the banking industry, banks are responsive to technology investments that permit them to reduce costs of back room operations and to facilitate innovations in financial products and delivery systems. Since an increase in our efficiency variable by construction suggests a higher degree of inefficiency, we expect a negative relationship between efficiency and Tobin's Q. We include non-traded and trading derivatives in the model since these instruments are used for hedging purposes (balance sheet risk management), trading purposes (profit motive) or some combination thereof. To the extent that derivatives reduce balance risk and represent a monopoly source of income we would expect that derivatives would exert a positive impact on charter value as proxied by Tobin's $\mathrm{Q}$. The notional value of market related derivatives may proxy as a continuing stream of future cash flows that a BHC might earn from related fees.

Previous studies have also found that macro-economic conditions influence bank charter value (cf. Keeley, 1990; Furlong and Kwan, 2006; Jones et al., 2011). Common to all BHCs, the macro-economic indicators included in this study are the Gross Domestic Product (GDP) percentage gap, the S\&P 500 inflation adjusted returns on the index and the 3-month U.S. Treasury bill rate. The GDP variable controls for the state of the business cycle while the S\&P 500 inflation adjusted index returns controls for changes in the condition of capital markets. Beforehand, we expect positive relationships between our GDP variable and the S\&P variable with Tobin's Q since it is well documented that 
business cycle conditions and overall stock market conditions seem to be directly correlated with Tobin's Q. The interest rate variable controls for the changes in rate environments that impact BHC net asset spreads. Since a rise in interest rates generally leads to a greater decline in the market value of BHC assets over liabilities, when asset duration is greater, we expect a negative relationship between the interest rate variable and Tobin's Q.

To investigate the effect of trading income and dealer designation on bank charter value proxied by Tobin's Q we present the following empirical model:

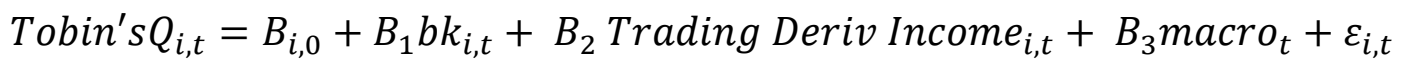

where Tobin's Q is computed as the quarterly ratio of the sum of the market value of equity plus the book value of total liabilities to BHC total assets; with $b k$ consisting of a vector of bank variables that include the log of BHC total assets along with net interest income, trading and non-trading derivatives, real estate loans and core deposits all scaled by $\mathrm{BHC}$ total assets and an efficiency variable measured as the ratio of BHC overhead to the sum of net interest and non-interest income; trading derivative income scaled by the sum of net interest and non-interest income ${ }^{8}$ which is our primary variable of interest, and macro which is a vector of macro variables that include GDP percentage gap, S\&P 500 inflation adjusted index returns and the 3-month U.S. Treasury bill rate. To avoid spurious regression results, the GDP gap, U.S.Treasury bill rate, real estate loans and core

\footnotetext{
${ }^{8}$ While acknowledging that non-interest income can be decomposed into two components: 1) trading income and 2) investment banking and venture capital income as employed by Brunnermeier et al. (2012), given the emphasis of derivative activity in our study we choose to focus on trading income in our model of BHC charter value proxied by Tobin's Q noting that non-interest income is used in our model to scale the efficiency and trading income variables.
} 
deposits variables enter the model in first difference 9 .

With this specification, we can test both research hypotheses. Specifically, if $\beta_{2}$ is significantly negative, it supports Hypothesis 1 that there is an inverse relationship between trading derivative incomes and bank charter value. On the other hand, if $\beta_{2}$ is significantly positive when interacted with the dealer indicator variable, it supports Hypothesis 2 that there is a direct relationship between trading derivative incomes by dealer banks sand bank charter value.

The model bears resemblance to the specification used by Jones et al. (2011) and Li and $\mathrm{Yu}(2010)$ with some unique differences. First, we introduce the trading income variable, our main variable of interest, that is absent in the specification by Jones et al. (2011). Although the trading income is controlled for in $\mathrm{Li}$ and $\mathrm{Yu}$ (2010), they focus on examining the impact of derivatives on bank performance, in terms of return on assets (ROA), and volatility in asset values using stock price volatility and option pricing modeling. Second, we control for derivatives dealer designation to explore behavior differences within our sample and the effects on charter value, proxied by Tobin's Q. Third, we incorporate trading and non-trading derivatives in our model which are omitted from Jones et al. (2011) specification while Li and Yu's (2010) control for only nontraded derivatives in their model. By including trading and non-trading derivatives in the model we set out to capture the full impact of derivative usage on charter value acknowledging that there may be differences in the underlying motivation for their use (i.e. balance sheet risk management vs. profit motives).

\footnotetext{
${ }^{9}$ We apply the Im-Pesaran-Shin's (2003) unit root test designed for panel data to all the model variables. The null of the test is that all panels contain unit roots. We conclude that with the exception of the real estate loans, core deposits, GDP gap and 3 month U.S. Treasury bill rate variables, at least one series in the panel is stationary. Unit root test tables are not reported in this study but are available upon request.
} 
We expand the benchmark model to incorporate two additional specifications. First, we introduce a financial crisis dummy variable that takes on the value of 1 during the crisis quarter 2007Q3 through 2008Q4 and zero otherwise. During the financial crisis Huerta et al. (2011) suggest that anxiety, fear and panic were prevalent emotions among investors which arguably contributed to the stock market volatility. During this period there was also heighten uncertainty with regards to the quality of bank balance sheets due to heavy exposures fueled by aggressive subprime lending activity. A priori we would expect that the financial crisis would have unfavorable impacts on charter value given the imbedded risks on bank balance sheet and on off-balance vehicles that had accumulated during the economic expansion period led by housing boom period. Therefore, we expect a negative relationship between the crisis indicator variable and Tobin's Q.

Second, we allow for the interaction between trading derivative incomes and dealer designation. We wish to examine whether the impact of trading income on charter value operates through the derivative dealer designation. A priori, if derivative dealers enjoy a monopolistic advantage in this market, we would expect that the impact on charter value would be favorable under the premise that trading incomes represent an important contribution to overall BHC incomes. Under this line of reasoning we would expect a positive relationship between trading income and Tobin's $\mathrm{Q}$ when trading income is interacted with the dealer designation indicator variable.

\section{Results}

\subsection{Panel Data Regression Analysis}

In Table 4 we report the results of our fixed effects panel estimations for the benchmark mark (Model 1) and the two alternative specifications (Models 2 and 3). In 
Model 2 we control for the potential impact of the financial crisis on BHC charter value through a dummy variable "crisis" ( 1 for the period between 2007Q3 and 2008Q4, and 0 otherwise) and in Model 3 we include an interaction term between trading income and dealer designation. The coefficients of the trading derivatives income variable, the primary variable of interest in this study, are negative in all models ranging from -0.162 in Model 1 to -0.542 in Model 3, yet statistically significant only in Model 3. These results can be linked to the study by Li and Yu's (2010) who find that trading incomes have no impact on BHC ROA while having a significant and positive correlation with the volatility of asset values. Trading's income impact on asset volatility and its null impact on ROA would suggest a negative impact, if any, on BHC charter value. Neither trading derivatives nor non-trading derivatives holdings have a statistically significant impact on BHC charter value. This result suggest that the risk reducing attributes of derivative activity may be subdued by un-hedged BHC risk attributes and other balance sheet uncertainties at minimum with regards to our sample and sample time frame. Furthermore, to the extent that trading derivatives are assets that belong to customers, there would be no risk taken by the BHC under this premise which would imply a nonimpact on charter value.

The positive and significant impact of net interest income on BHC charter value in all three models is consistent with empirical findings in the BHC charter literature. The coefficients range from 0.362 in Model 3 to 0.374 in Model 2, and are significant at the $5 \%$ level, suggesting that this source of operational market power leads to improved BHC charter value. The results support the view that BHCs retain a form pricing power that allows them to set loan yields at above market rates will attracting funds, mainly insured 
demand deposits, at below-market rates. The coefficients on the core-deposit variable are negative and modestly significant at the $10 \%$ level in all three models ranging from 0.182 in Model 3 to -0.198 in Model 2. This result is inconsistent with theory yet it is not surprising given the trend that we observe in the Tobin's Q and core-deposit series graphed in Figures 5 and 6 respectively. There has been a general downward trend in Tobin's Q over the sample period while bank core-deposits, a common measure of market power, have been on the rise. Jones et al. (2011) conclude that BHC charter value, proxied by Tobin's Q, has been on the decline given the increase risk-taking by banks that led to the subprime financial crisis. Cornett et al. (2011) suggest that during the financial crisis period funds were leaving the securities market and flowing into the banking system with most of these funds going into transaction deposits. While a rise in core deposits implies an increase in market power that ceteris paribus should translate to an improved charter value, the Tobin's Q and Core Deposit series depicted in Figures 5 and 6 suggest that there may be other forces that are unrelated to market power that are driving the results.

While the BHC total assets, efficiency and real estate variables are of the expected sign, only the BHC total asset variable are statistically significant in all three specifications ranging from -0.127 in Model 1 to -0.124 in Models 2 and 3. The negative and significant coefficient on the BHC total asset variable supports the view that there are diseconomies of scale such as those related to technology investments that the larger banks are commonly exposed. Alternatively the negative coefficients may also signal restrictions regarding the potential for continued potential growth that constrain the larger banks. 
The coefficients on the GDP and interest rate variables are of the expected sign yet only significant in the case of the GDP variable ranging from 1.498 in Model 3 to 1.617 in Model 1. The positive and significant effect of the GDP variable suggests that the business cycles influence $\mathrm{BHC}$ charter value. It is common for BHC to enjoy higher profits during business cycle booms that are accompanied by an economic environment that exhibits strong loan demand and high credit quality. Conversely, BHC charter values would be expected to diminish if BHCs record falling profits during periods of economic contraction. Interestingly, the coefficients on the S\&P 500 variable are negative yet statistically insignificant in all 3 models ranging from -0.020 in Model 1 to -0.026 in Model 2. This result, while not statistically significant, is at odds with the findings by Jones et al. (2011) who claim that Tobin's Q measures of charter value are heavily influenced by price-earnings ratios and overall stock market performance. These authors contend that if markets fail to adequately discount assets to account for their imbedded risk, Tobin's Q would remain high during periods when the high-risk assets are generating strong profits. Eventually Tobin's Q would be adjusted downward once the risk become apparent and the market value of the assets adjust accordingly. The small negative, coefficients on the $\mathrm{S} \& \mathrm{P}$ variable are not entirely surprising given the trend that we observe in the Tobin's Q and S\&P 500 series graphed in Figures 5 and 7 respectively. While Tobin's Q series reflects downward trends given the events (and resulting outcomes) that negatively impacted the banking industry (i.e. balance uncertainty, excessive risk taking, subprime lending, losses and increasing leverage, among others), the returns on the S\&P 500 index, that captures multiple industries, reflects a volatile yet fairly flat trend over the sample period. 
To the extent that the financial crisis had any impact on BHC charter value we would presume that its effect would be negative. During the financial crisis period BHCs were highly concerned about balance sheet valuations (as well as those of their competitors). Furthermore, they were exposed to significant liquidity constraints and overall financial market disruption. The coefficients on the financial crisis dummy variable are negative yet not significant. The positive and significant coefficient in the interaction term between trading income and dealer designation included in Model 3 is an interesting result. The implication is that dealer banks (as opposed to non-dealer banks) are well equipped to adequately manage risk and are able to benefit from profitable trading activities that favorably impact BHC charter value.

\subsection{Quartile Ranking Analysis}

Some researchers including Jones et al. (2011) suggest that the cardinal properties of Tobin's Q as a proxy for charter value are inadequate since Tobin's Q values are largely influenced by external factors such as price earnings ratios and overall stock market conditions that are not necessarily connected to market power. Furthermore, while charter value is typically viewed as a long-term slow-moving financial investment concept that is based on a firm's ability to generate ongoing economic profits, Tobin's Q values reflect large swings in unison with changes in the business cycle. Based on this line of reasoning, Tobin's Q is arguably a poor cardinal measure of charter value (i.e. Tobin's Q is unable to adequately measure the amount of change in the magnitude of charter value).To mitigate this issue, we reexamine our research questions relying on the ordinal properties of Tobin's Q in a similar fashion that was employed by Jones et al. (2011).

Under the view that Tobin's Q has adequate ordinal properties, at any given point in 
time those BHCs that have the higher Tobin's Q values (compared to the BHC's with the lower Tobin's Q values) may have the stronger incentive to refrain from risk-taking under the assumption that $\mathrm{BHC}$ wish to preserve the economic benefits that are realizable through the granting of the charter. Jones et al. (2011) explain that in an effort to retain their competitive advantage, BHC take on less risk by holding more capital as their charter value increases. Before hand, we would anticipated that BHCs with higher charter values upon entering the crisis period should perform better compared to their counterparts under the premise that charter preservation matters.

To conduct our analysis based on the ordinal properties of Tobin's Q we first categorize the Tobin's Q values as of 2006Q4 for the BHC in the sample into quartiles with the first quartile comprised of the BHC with the lowest Tobin's Q value with the $4^{\text {th }}$ quartile consisting of BHC's with the highest Tobin's Q values. Next, we compute the mean values for the risk variable (Tier 1 Capital Ratio) along with the mean values for the efficiency and trading derivative variables by quartile. We also compute the mean values of the changes in the referenced variables between 2006Q4 and 2008Q4 by quartile. If Tobin's Q is useful measure of BHC charter value then we should see a negative correlation between Tobin's Q in 2006Q4 and the level of (and changes in) risk at 2008Q4 if preservation of charter value is relevant.

Panel A in Table 5 suggests that BHC with the highest Tobin's Q values had the stronger balance sheets as evidenced by the Tier 1 capital ratios as of 2008Q4 compared to capital ratios of the BHCs that reported the lowest levels of Tobin's Q. The difference in the Tier 1 capital ratios between these two groups however is statistically insignificant (p-value of 0.910). While the BHCs with the highest Tobin's Q value at 2006Q4 also 
reported better efficiency measures in 2008Q4 compared to the BHC's in the lowest quartile (0.672 vs. 0.790$)$, the difference between the groups was not statistically significant. BHC's with the highest Tobin's Q values at 2006Q4, reflected lower levels of trading derivative positions as of 2008Q4, which would imply some form of risk aversion, yet this group of BHCs outperformed their peers that are ranked with the lowest Tobin's Q values in terms of trading incomes. Similar conclusions are reached in examining Panel B of Table 5 in terms of changes in the variable values between 2006Q4 and 2008Q4 yet again the group differences were statistically insignificant. Some interesting, albeit not statistically significant, observations in Panel B of Table 5 is that the BHC's with the lowest Tobin's Q values reduced their exposures to trading derivatives while the highest Tobin's Q group of BHCs reported a small increase in trading derivatives yet with virtually no change in trading derivative incomes between 2006Q4 and 2008Q4.

During the height of the financial crisis period 2007Q3 to 2008Q4, all but four BHCs (i.e. State Street Corporation, Wells Fargo \& Co, Key Corporation and Regions Financial Corporation), reported cumulative trading losses. The pre-crisis charter value, proxied by Tobin's Q as of 2006Q4 for these four BHC's reflected no discernible pattern. State Street and Wells Fargo are ranked in the highest Tobin's Q quartile while Key Corporation and Regions Financial Corporation are ranked in the second lowest and the lowest quartiles respectively. The largest trading losses were reported by derivative dealer BHCs Citigroup and Bank of America Corporation whose Tobin's Q ranked in the lower quartiles (i.e. weaker BHC charter values). While there are large differences in asset size and core deposit holdings between dealer and non dealer BHCs, dealer BHC 
witness growth in quarterly trading revenues during the sample period while non-dealer BHCs reported a contraction in quarterly trading income activity.

We conduct robustness checks that are presented in Models 1 through 3 in Table 6. As an initial attempt to capture the potential dynamic interactions between bank charter value (proxied by Tobin's Q) and its determinants (the right hand side variables in our model) as well as the persistence in the Tobin's Q series, we allow for a lag value of Tobin's Q to enter our fixed effects specification in Model 1. The findings are generally consistent with our expectations in that trading derivative incomes do not favorably impact bank charter value based on the statistically insignificant coefficient of -0.017 in Model 1. On the other hand we do not find evidence of a positive relationship between trading derivative incomes by dealer banks and bank charter value. We reach similar conclusions in Model 2 in which we replace the current trading derivative income with a lag of itself.

In Model 3 we explore an alternative proxy of bank charter value that is defined as the ratio of core deposits to $\mathrm{BHC}$ total deposits, a proxy that was introduced by Jones et al. (2011). Interestingly, we find that trading derivative incomes have a positive impact on bank charter value based on the statistically significant coefficient of 0.885 while the interaction between trading derivative incomes and dealer banks has a negative impact based on the statistically significant coefficient of -0.985 reported in Model 3. The findings in Model 3 that at first glance seem to be at odds with our hypotheses are not necessarily surprising. A visual inspection of Figures 3 and 4 which depict the Tobin's $Q$ and the core deposit series respectively show two opposing patterns. For a greater part of the time span covered, Tobin's $Q$ has been in a general downward trend in part due to the 
increase risk-taking activities by banks that led to the financial crisis while since the latter part of 2007 bank core deposit have sharply increased. The banks received a significant influx of liquidity through Federal Reserve Bank expansion activity (multiple rounds of quantitative easing) and as a result of a massive restructure of the financial sector balance sheets. The inconsistency in the findings based on the use of different proxies of bank charter value (i.e. Tobin's Q vs. core deposits) lends support to the general conclusion by Jones et al. (2011) regarding the reliability of Tobin's Q as key measure of charter value.

\section{Conclusion}

This paper examines the relationship between derivative trading income and charter value for 27 bank holding companies (BHC) between 2001Q1 and 2011Q3. This paper is motivated by the continued evolution in derivative securities, and the significant trading losses recorded during the 2007-2009 financial crises, that have drawn attention to bank regulators, law makers and the investor public. There are some researchers who contend that off-balance-activities, including derivatives trading, have become a potential source of bank charter value for the large banks. To the extent that derivatives reduce balance risk (used for hedging purposes) and represent a monopoly source of income (used for trading/profit purposes) we would expect that derivatives would exert a positive impact on charter value as proxied by Tobin's $Q$.

The findings in this paper suggests that trading incomes have a negative impact on BHC charter value suggesting that derivative activity is driven more by profit as opposed to hedging motives. This finding implies that BHCs increase risk through their offbalance sheet activities that generate volatile trading revenues. We also find that while 
that trading income has a negative impact on $\mathrm{BHC}$ charter value, the impact becomes positive when trading income is interacted with derivative dealer designation. This finding implies that dealer banks (as opposed to non-dealer banks) are well equipped to adequately manage risk and are able to benefit from profitable trading activities that favorably impact BHC charter value. In any event, trading income's contribution to BHC charter value is most likely damped by the fact that trading income is only a small fraction of BHCs' net operating revenue and is highly volatile. On this basis, we are inclined to believe that any contribution of trading incomes to BHC charter value may be suspect at best. Finally, we observe that trading income did not contribute to overall BHC income during the financial crisis. 


\section{References}

Ashraf, Dawood, Yener Altunbas and John Goddard. (2007). "Who Transfers Credit Risk? Determinants of the Use of Credit Derivatives by Large U.S. Banks." The European Journal of Finance, Vol.13, 483-500.

Berger, Allen. (2003). "The Economic Effects of Technological Progress: Evidence from the Banking Industry." Journal of Money, Credit and Banking, Vol.35, 143-176.

Brunnermeier,Markus Gang Dong, and Darius Palia.(2012). "Bank's Non-Interest Income and Systemic Risk.” Working Paper. Princeton University

Chaudhry, Mukesh, Rohan Christie-David, Timothy Koch and Alan Reichert. (2000). "The Risk of Foreign Currency Contingent Claims at U.S. Commercial Banks." Journal of Banking and Finance, Vol.24, 1399-1417.

Cornett, Marcia, Jamie McNutt, Phillip Strahand and Hassan Tehranian. (2011). "Liquidity Risk Management and Credit Supply in the Financial Crisis." Journal of Financial Economics, Vol.101, 297-312.

De Nicolo, Gianni. (2001)." Size, Charter Value and Risk in Banking: An International Perspective." International Finance Discussion Paper no.689 Board of Governors of the Federal Reserve System.

Duffie, Darrell. (2010). "The Failure Mechanics of Dealer Banks." Journal of Economic Perspectives, Vol.24,51-72.

Fitzpatrick, Dan, Gregory Zuckerman and Liz Rappaport. (2012). “J.P. Morgan’s \$2 Billion Blunder.” The Wall Street Journal May 11, 2012.

Furlong, Frederick and Simon Kwan. (2006). "Sources of Bank Charter Value.” Working Paper, Federal Reserve Bank of San Francisco.

Huerta, Daniel, Daniel Perez-Liston and Dave Jackson. (2011). "The Impact of TARP Bailouts on Stock Market Volatility and Investor Fear." Banking and Finance Review, Vol.1, 45-54.

Keeley, Michael. (1990). "Deposit Insurance, Risk, and Market Power in Banking." The American Economic Review, Vol. 80,1183-1200.

Im, Kyung-So, M. Hashem Pesaran and Yongcheol Shin. (2003). "Testing for Unit Roots in Heterogeneous Panels." Journal of Econometrics, Vol. 115, 53-74.

Instefjord, Norvald. (2005). "Risk and Hedging: Do Credit Derivatives Increase Bank Risk?" Journal of Banking and Finance, Vol.29, 333-345.

Jones, Jeffrey, Scott Miller and Timothy Yeager. (2011). "Charter Value, Tobin's Q and Bank Risk During the Subprime Financial Crisis." Journal of Economics and 
Business, Vol.63, 372-391.

Li, Li and Zhang Yu. (2010). "The Impact of Derivatives Activity on Commercial Banks: Evidence from U.S. Bank Holding Companies." Asian-Pacific Financial Markets, Vol.17, 303-322.

Minton, Bernadette, Rene Stulz and Rohan Williamson. (2009). "How Much do Banks Use Credit Derivatives to Hedge Loans?” Journal of Financial Services Research, Vol.35, 1-31.

OCC (2011). "OCC's Quarterly Report on Bank Trading and Derivatives Activities Fourth Quarter 2011." Washington, D.C. Office of the Comptroller of the Currency http://www.occ.treas.gov/topics/capital-markets/financialmarkets/trading/derivatives/derivatives-quarterly-report.html

Palia, Darius and Robert Porter. (2004). "The Impact of Capital Requirements and Managerial Compensation on Bank Charter Value." Review of Quantitative Finance and Accounting, Vol.23, 191-206.

Purnanandam, Amiyatosh. (2007). "Interest Rate Derivatives at Commercial Banks: An Empirical Investigation." Journal of Monetary Economics, Vol.54, 1769-1808.

Reichert, Alan and Yih-Wen Shyu. (2003). "Derivative Activities and the Risk of International Banks: A Market Index and VaR Approach." International Review of Financial Analysis, Vol. 12, 489-511.

Sinkey, Joseph and David Carter. (2000). "Evidence on the Financial Characteristics of Banks that Do and Do Not Use Derivatives."The Quarterly Review of Economics and Finance, Vol.40, 431-449.

Stiroh, Kevin. (2004). "Diversification in Banking: Is Noninterest Income the Answer?" Journal of Money, Credit and Banking, Vol.35, 853-882.

Turk-Ariss, Rima. (2010).On the Implications of Market Power in Banking: Evidence from Developing Countries." Journal of Banking and Finance, Vol.34, 765-775.

Zhao, Fang and Jim Moser. (2009). "Use of Derivatives and Bank Holding Companies' Interest-Rate Risk." Banking and Finance Review, Vol.1, 51-62. 
Figure 1 Derivative Contracts Market-Herfindahl index

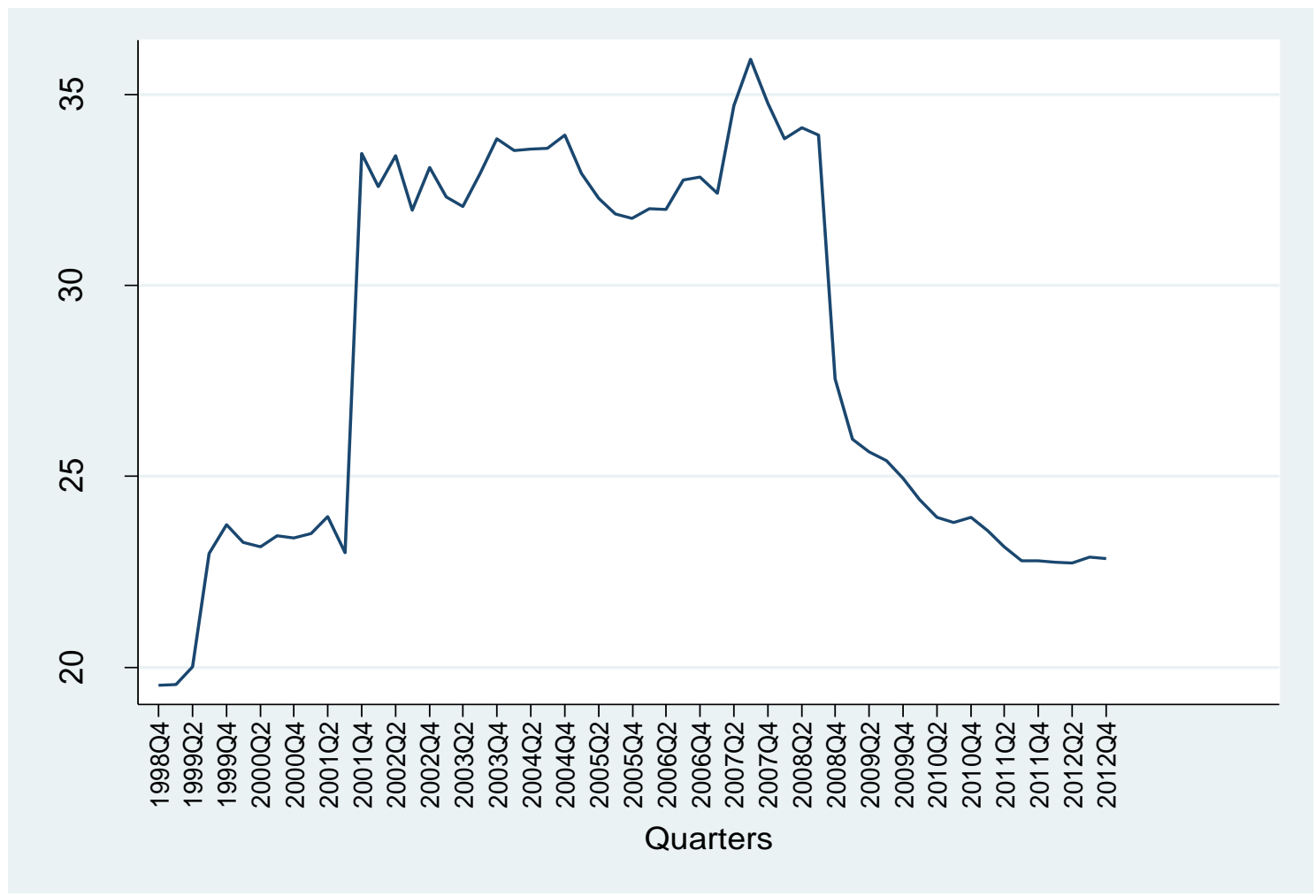

Notes: The Herfindahl Index is computed from the reported notional amounts of derivative contracts outstanding for each of the top 25 commercial banks, savings and loans associations (S\&Ls) and trust companies (TCs) along with aggregate notional amounts for the remaining commercial banks, S\&L's and TC's that engage in derivative activity. The information is extracted from the quarterly reports of derivative activities that are available through the U.S. Department of the Treasury's Office of the Comptroller of the Currency (OCC) at the following website (http://www.occ.treas.gov/topics/capital-markets/financial-markets/trading/derivatives/derivatives-quarterlyreport.html) last accessed on 8/21/13. 
Figure 2 Derivative and total asset growth

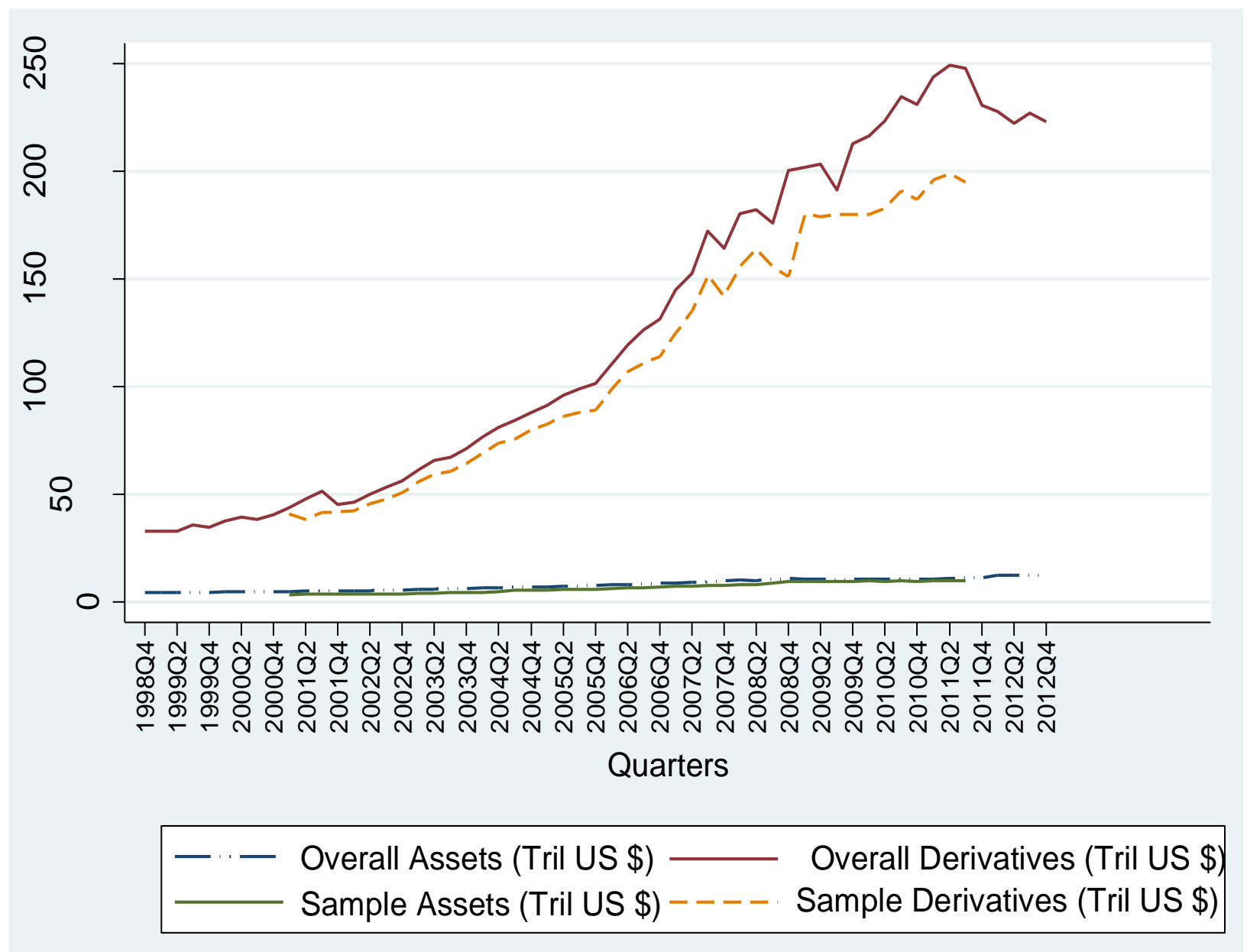

Notes: The dashed line identified as "sample derivatives" represents the sum of total trading derivatives held by the 27 bank holding companies (BHC) in our sample. The solid line identified as "sample assets" constitutes the sum of total assets held by the 27 BHCs in the sample. Both series cover the sample period from 2001Q1 to2011Q3. The solid line identified as "overall derivatives" captures the total notional amount of derivative contracts outstanding for each of the top 25 commercial banks, savings and loans associations (S\&Ls) and trust companies (TCs) along with aggregate notional amounts for the remaining commercial banks, S\&L's and TC's that engage in derivative activity. The dash dotted dash line identified as "overall assets" represents the sum of the total assets of those commercial banks, S\&L's and TC that are engaged in derivative activity and that correspond to the institutions included in the "overall derivative" series. The "overall assets" and "overall derivative" series cover the period from 1998Q4 to 2012Q4. The information for the "overall derivative" and "overall asset" series are extracted from the quarterly reports of derivative activities that are available through the U.S. Department of the Treasury's Office of the Comptroller of the Currency (OCC) at the following website (http://www.occ.treas.gov/topics/capitalmarkets/financial-markets/trading/derivatives/derivatives-quarterly-report.html)last accessed on 8/21/13. 
Figure 3 Trading revenues scaled by net interest and non interest income

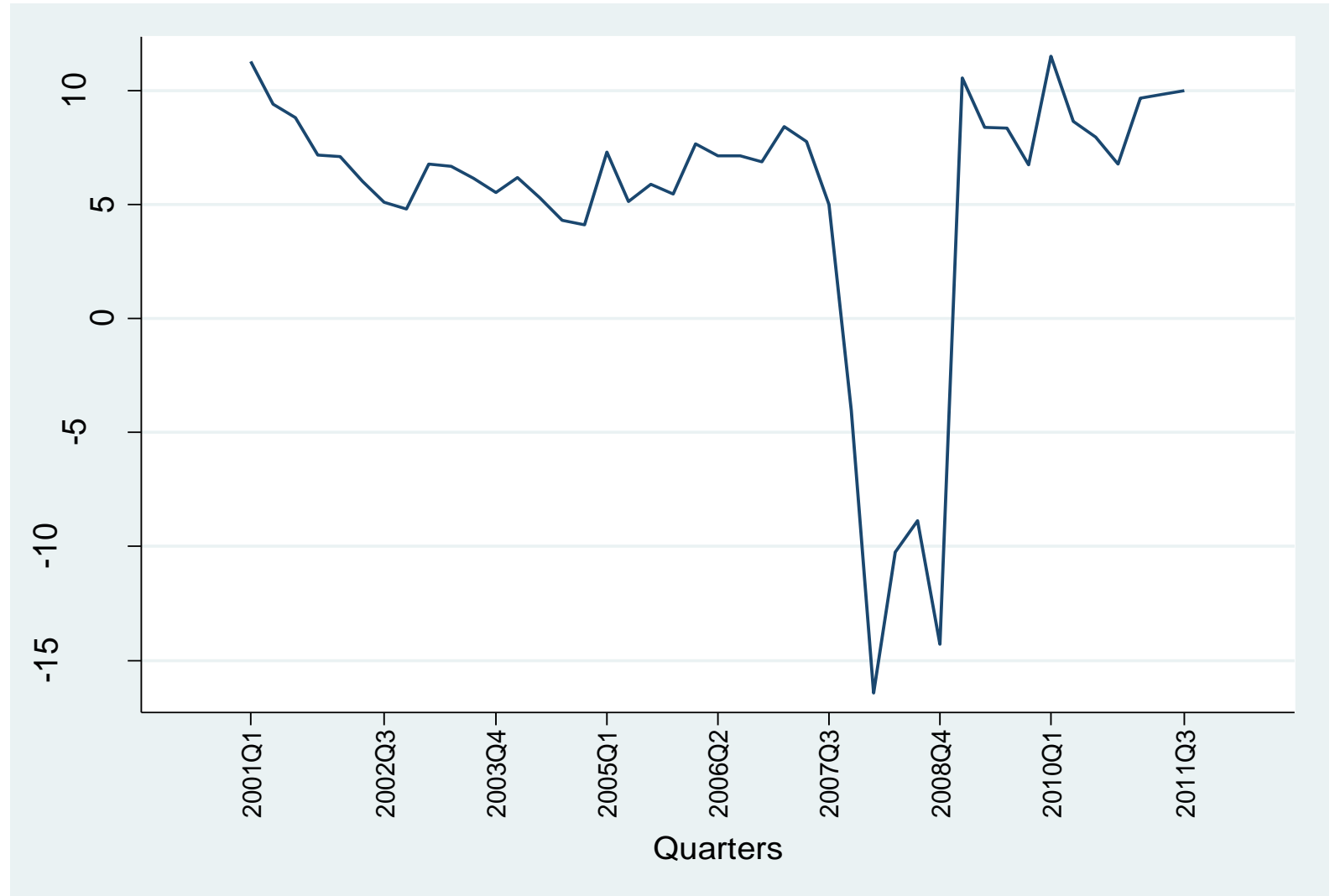

Notes: These series represent asset weighted mean trading revenues scaled by the sum of net interest income and non-interest income for the 27 bank holding companies (BHC) in the sample. The series cover the full sample period from 2001Q1 to 2011Q3. 
Figure 4 Trading revenues of U.S. Commercial Banks

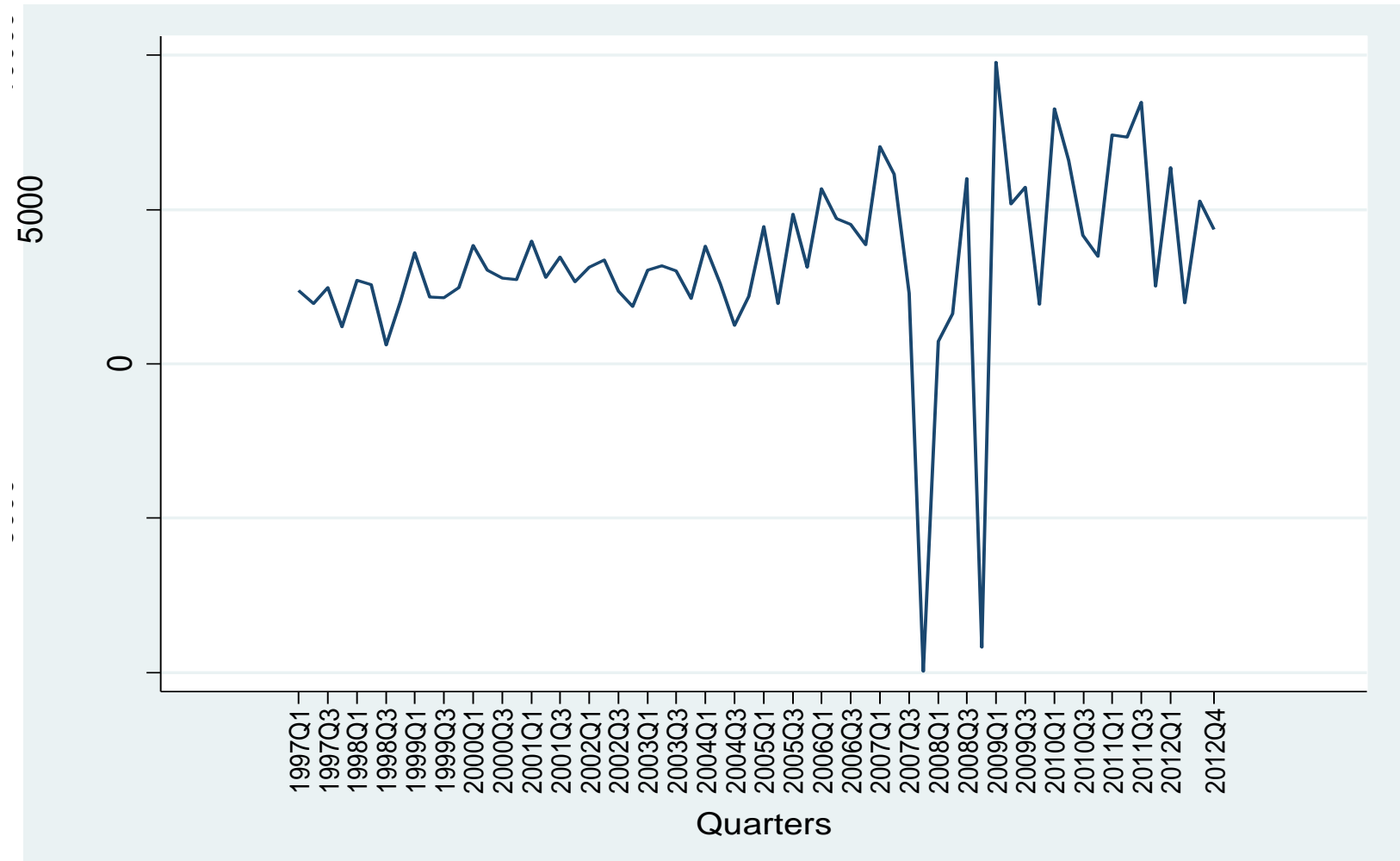

Notes: These series represent quarterly trading revenues from cash and derivative activities by insured U.S. commercial banks. Revenue figures are quarterly data as opposed to cumulative data. The information is extracted from the quarterly reports of derivative activities that are available through the U.S. Department of the Treasury's Office of the Comptroller of the Currency (OCC) at the following website (http://www.occ.treas.gov/topics/capitalmarkets/financial-markets/trading/derivatives/derivatives-quarterly-report.html)last accessed on 8/21/13. 
Figure 5 Tobin's Q Trend

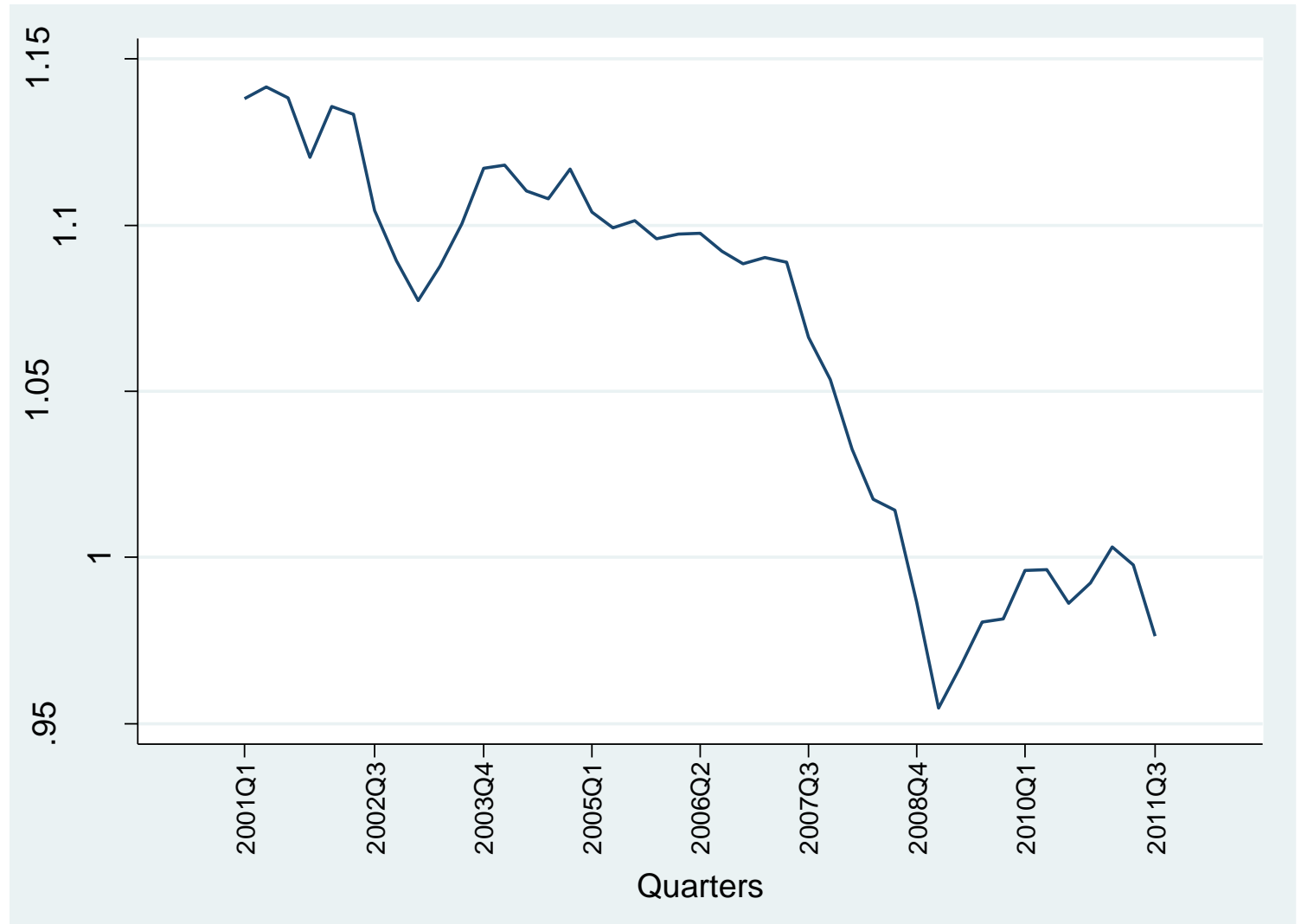

Notes: The series represents the mean Tobin's Q for the 27 bank holding companies (BHC) in the sample. The Tobin's Q measure is calculated on a quarterly basis and consists of the ratio of the sum of the market value of equity plus the book value of total BHC liabilities divided by BHC total assets. The quarterly market value of equity is derived from the monthly market capitalization data for each of the BHCs that are available through the Bloomberg data base (http://bloomberg.com). The BHCs total liabilities and assets information is extracted from quarterly call reports that are available through the Federal Reserve Bank of Chicago data base at the following website: https://www.chicagofed.org/applications/bhc_data/bhcdata_index.cfm. The series cover the full sample period from 2001Q1 to 2011Q3. 


\section{Figure 6 Core Deposit Trend}

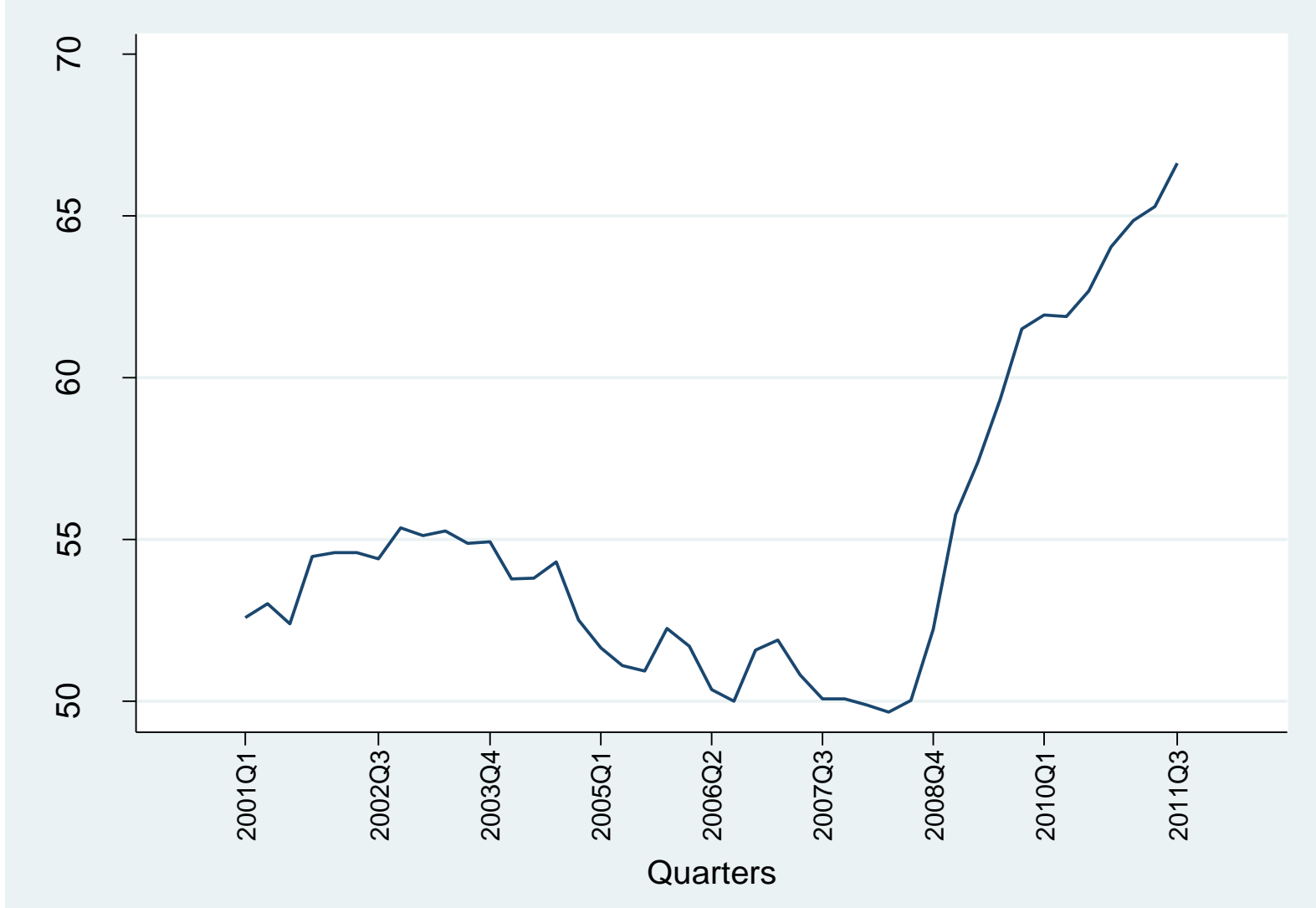

Notes: The series represents the mean core deposits scaled by BHC total liabilities for the 27 bank holding companies (BHC) in the sample. Core deposits include the sum of non-interest bearing and interest bearing demand deposits, money market and savings accounts plus time deposits < U.S. $\$ 100,000$. The series cover the full sample period from 2001Q1 to 2011Q3. 
Figure 7 S\&P 500 index returns

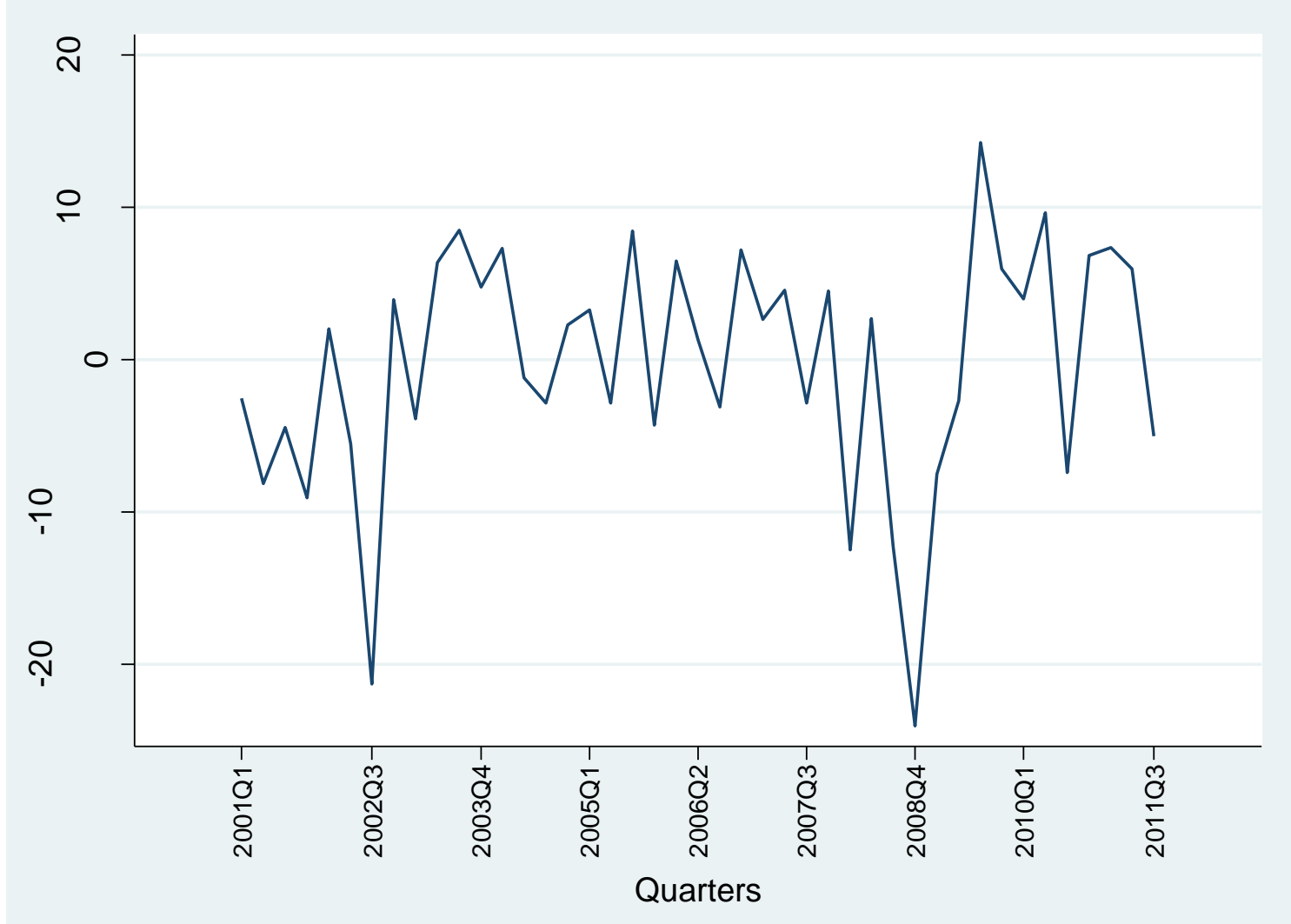

Notes: The series represents the Standard \& Poors (S\&P) 500 inflation-adjusted returns on the index. The S\&P 500 index returns series is derived from data that is available through Thomson Reuter's Datastream. The series cover the full sample period from 2001Q1 to 2011Q3. 


\begin{tabular}{|c|c|c|c|c|c|c|c|c|}
\hline & Total Assets & $\begin{array}{l}\text { Net Interest } \\
\text { Income- } \\
\text { standardized by } \\
\text { avg assets }\end{array}$ & $\begin{array}{l}\text { Trading } \\
\text { Derivatives- } \\
\text { standardized by } \\
\text { total assets }\end{array}$ & $\begin{array}{l}\text { Trading Derivative } \\
\text { Income } \\
\text { standardized by } \\
\text { net operating } \\
\text { revenue }\end{array}$ & $\begin{array}{l}\text { Real Estate } \\
\text { Loans } \\
\text { standardized by } \\
\text { total assets }\end{array}$ & Efficiency & $\begin{array}{l}\text { Core Deposits } \\
\text { standardized } \\
\text { by total } \\
\text { liabilities } \\
\end{array}$ & $\begin{array}{l}\text { Non Traded } \\
\text { Derivatives- } \\
\text { standardized by } \\
\text { total assets }\end{array}$ \\
\hline \multicolumn{9}{|c|}{ Full sample- Panel A } \\
\hline mean & $260,639,045$ & $1.90 \%$ & $326.44 \%$ & $3.09 \%$ & $34.84 \%$ & $63.10 \%$ & $54.94 \%$ & $20.85 \%$ \\
\hline median & $64,733,769$ & $1.75 \%$ & $19.38 \%$ & $1.32 \%$ & $34.18 \%$ & $61.01 \%$ & $61.03 \%$ & $12.73 \%$ \\
\hline Std. Dev. & $508,518,644$ & $1.02 \%$ & $875.94 \%$ & $6.07 \%$ & $14.84 \%$ & $19.41 \%$ & $21.20 \%$ & $27.15 \%$ \\
\hline Min & $6,239,843$ & $0.21 \%$ & $0.00 \%$ & $-49.73 \%$ & $0.00 \%$ & $39.44 \%$ & $0.86 \%$ & $0.00 \%$ \\
\hline Max & $2,370,594,235$ & $6.30 \%$ & $5704.55 \%$ & $40.52 \%$ & $63.56 \%$ & $517.91 \%$ & $91.20 \%$ & $242.93 \%$ \\
\hline \multicolumn{9}{|c|}{ Derivatives dealer- Panel B } \\
\hline mean & $722,675,006$ & $1.63 \%$ & $1064.53 \%$ & $4.47 \%$ & $24.50 \%$ & $64.44 \%$ & $41.14 \%$ & $32.25 \%$ \\
\hline median & $341,754,500$ & $1.50 \%$ & $292.13 \%$ & $2.91 \%$ & $26.56 \%$ & $61.56 \%$ & $49.33 \%$ & $17.89 \%$ \\
\hline Std. Dev. & $734,147,890$ & $0.93 \%$ & $1364.41 \%$ & $7.55 \%$ & $14.85 \%$ & $11.89 \%$ & $23.71 \%$ & $37.99 \%$ \\
\hline Min & $66,409,507$ & $0.21 \%$ & $11.60 \%$ & $-49.73 \%$ & $0.00 \%$ & $45.71 \%$ & $0.86 \%$ & $0.21 \%$ \\
\hline Max & $2,370,594,235$ & $4.54 \%$ & $5704.55 \%$ & $25.66 \%$ & $53.04 \%$ & $159.74 \%$ & $77.81 \%$ & $242.39 \%$ \\
\hline \multicolumn{9}{|c|}{ Non dealer- Panel C } \\
\hline mean & $58,662,393$ & $2.01 \%$ & $22.74 \%$ & $2.49 \%$ & $39.34 \%$ & $62.51 \%$ & $60.94 \%$ & $15.89 \%$ \\
\hline median & $32,753,772$ & $1.92 \%$ & $4.71 \%$ & $0.86 \%$ & $40.04 \%$ & $60.66 \%$ & $63.18 \%$ & $9.38 \%$ \\
\hline Std. Dev. & $60,858,544$ & $1.04 \%$ & $44.20 \%$ & $5.19 \%$ & $12.39 \%$ & $21.88 \%$ & $16.80 \%$ & $18.71 \%$ \\
\hline Min & $6,239,843$ & $0.25 \%$ & $0.00 \%$ & $-10.51 \%$ & $0.07 \%$ & $39.44 \%$ & $1.97 \%$ & $0.00 \%$ \\
\hline $\operatorname{Max}$ & $330,141,000$ & $6.30 \%$ & $287.78 \%$ & $40.52 \%$ & $63.56 \%$ & $517.91 \%$ & $91.20 \%$ & $132.16 \%$ \\
\hline
\end{tabular}

Notes: Total assets are expressed in levels and in thousands of dollars while all other bank variables are expressed in ratio form. The descriptive detail is computed for the entire sample period from 2001Q1 to 2011Q3. The data is extracted from Consolidated Financial Statements for Bank Holding Companies (call report form FR-Y- 9C) that are submitted on a quarterly basis to the Federal Reserve. The data is available through the Federal Reserve Bank of Chicago data base at the following website https://www.chicagofed.org/applications/bhc_data/bhcdata_index.cfm last accessed on 9/20/12. The full sample includes 27 bank holding companies (BHC). Dealer banks include: JP Morgan Chase \& Co, Bank of America Corporation, Citigroup, Wellsfargo \& Co., State Street Corporation, Regions Financial Corp, PNC Financial Services Group Inc and Key Corp. For the full list of sample banks refer to Appendix A. Author's calculations. 
Table 2. Sample BHC size, asset growth, capitalization, trading revenue and derivative growth

\begin{tabular}{|c|c|c|c|c|c|}
\hline & $\begin{array}{l}\text { Total Assets at } \\
2011 Q 3\end{array}$ & $\begin{array}{l}\text { Quarterly Asset } \\
\text { Growth (\%) } \\
\text { 2001Q1-2011Q3 }\end{array}$ & $\begin{array}{l}\text { Tier } 1 \text { risk based } \\
\text { capital ratio at } \\
2011 Q 3\end{array}$ & $\begin{array}{l}\text { Quarterly Trading } \\
\text { Income growth } \\
\text { (\%) 2001Q1- } \\
2011 Q 3 \\
\end{array}$ & $\begin{array}{l}\text { Quarterly Trading } \\
\text { Derivatives growth } \\
\text { (\%) 2001Q1- } \\
2011 Q 3 \\
\end{array}$ \\
\hline \multicolumn{6}{|c|}{ Full sample- Panel A } \\
\hline mean & $380,561,576$ & $1.69 \%$ & 13.004 & $-62.58 \%$ & $1995.00 \%$ \\
\hline median & $92,751,923$ & $1.29 \%$ & 12.840 & $0.00 \%$ & $0.00 \%$ \\
\hline Std. Dev. & $699,837,914$ & $5.03 \%$ & 1.84 & $2127.52 \%$ & $66092.37 \%$ \\
\hline Min & $13,475,572$ & $-38.39 \%$ & 10.320 & $-69060.29 \%$ & $-100.00 \%$ \\
\hline Max & $2,289,240,000$ & $48.53 \%$ & 17.870 & $6440.51 \%$ & $2200000.00 \%$ \\
\hline \multicolumn{6}{|c|}{ Derivatives dealer- Panel B } \\
\hline mean & $1,055,932,717$ & $1.76 \%$ & 13.206 & $22.33 \%$ & $4.58 \%$ \\
\hline median & $787,250,233$ & $1.39 \%$ & 12.980 & $-5.69 \%$ & $3.03 \%$ \\
\hline Std. Dev. & $988,981,195$ & $5.80 \%$ & 2.068 & $448.65 \%$ & $14.43 \%$ \\
\hline Min & $89,405,605$ & $-38.39 \%$ & 11.260 & $-1331.17 \%$ & $-31.55 \%$ \\
\hline Max & $2,289,240,000$ & $39.21 \%$ & 17.870 & $6440.51 \%$ & $156.83 \%$ \\
\hline \multicolumn{6}{|c|}{ Non dealer- Panel C } \\
\hline mean & $78,174,644$ & $1.67 \%$ & 12.919 & $-97.63 \%$ & $2803.29 \%$ \\
\hline median & $38,179,000$ & $1.28 \%$ & 12.560 & $0.00 \%$ & $0.00 \%$ \\
\hline Std. Dev. & $84,537,353$ & $4.68 \%$ & 1.789 & $2510.63 \%$ & $78371.42 \%$ \\
\hline Min & $13,475,572$ & $-13.84 \%$ & 10.320 & $-69060.29 \%$ & $-100.00 \%$ \\
\hline Max & $330,141,000$ & $48.53 \%$ & 16.100 & $4300.00 \%$ & $2200000.00 \%$ \\
\hline
\end{tabular}

Notes: Total assets are expressed in thousands of dollars while the bank tier 1 risk capital measure is in ratio form. Quarterly assets and trading derivatives growth rates are based on a simple computation: \{(value present quarter- value prior quarter)/value prior quarter $\}$. The quarterly trading revenues are annualized prior to computing the quarterly growth rates. 
Table 3. Correlation matrix of independent variables, sample period 2001Q1-2011Q3

\begin{tabular}{|c|c|c|c|c|c|c|c|c|c|c|c|c|c|}
\hline & $\begin{array}{c}\text { BHC Total } \\
\text { Assets }\end{array}$ & $\begin{array}{l}\text { Net Interest } \\
\text { Income-std }\end{array}$ & $\begin{array}{c}\text { Trading } \\
\text { Deriv- std }\end{array}$ & $\begin{array}{l}\text { Trading } \\
\text { Deriv } \\
\text { Income- } \\
\text { std }\end{array}$ & $\begin{array}{c}\text { R/E loans- } \\
\text { std }\end{array}$ & Efficiency & GDP \% GAP & $\begin{array}{l}\text { S\&P } 500 \\
\text { index ret }\end{array}$ & TB3MOS & $\begin{array}{c}\text { Core } \\
\text { Deposits- } \\
\text { std }\end{array}$ & $\begin{array}{c}\text { Non } \\
\text { Trading } \\
\text { Deriv-std }\end{array}$ & Crisis & Dealer \\
\hline BHC Total Assets & 1.0000 & & & & & & & & & & & & \\
\hline Net Interest Income-std & -0.1283 & 1.0000 & & & & & & & & & & & \\
\hline Trading Deriv-std & 0.6670 & -0.2065 & 1.0000 & & & & & & & & & & \\
\hline Trading Deriv Income-std & 0.1423 & -0.2208 & 0.3095 & 1.0000 & & & & & & & & & \\
\hline R/E loans-std & -0.0275 & 0.0287 & -0.0135 & -0.0414 & 1.0000 & & & & & & & & \\
\hline Efficiency & -0.0352 & -0.1094 & 0.0283 & 0.0297 & 0.0068 & 1.0000 & & & & & & & \\
\hline GDP \% GAP & -0.0315 & -0.0170 & 0.0022 & 0.0825 & 0.0081 & -0.1247 & 1.0000 & & & & & & \\
\hline S\&P 500 index ret & 0.0176 & -0.0939 & 0.0143 & 0.0884 & -0.0317 & -0.0368 & 0.6688 & 1.0000 & & & & & \\
\hline TB3MOS & -0.0125 & -0.0625 & -0.0003 & 0.0803 & 0.0675 & -0.0065 & 0.4829 & 0.3506 & 1.0000 & & & & \\
\hline Core Deposits-std & 0.0069 & 0.1098 & -0.0105 & -0.0030 & 0.1538 & 0.0979 & -0.1493 & -0.0610 & 0.0048 & 1.0000 & & & \\
\hline Non Trading Deriv-std & 0.3428 & 0.1003 & 0.0200 & 0.1085 & 0.0402 & -0.0190 & 0.0247 & -0.0111 & 0.0089 & -0.0218 & 1.0000 & & \\
\hline Crisis & 0.0592 & 0.0553 & 0.0145 & -0.1721 & -0.0327 & -0.0015 & -0.4399 & -0.3731 & -0.5272 & -0.0201 & -0.0316 & 1.0000 & \\
\hline Dealer & 0.7086 & -0.1714 & 0.5384 & 0.1417 & -0.0268 & 0.0439 & -0.0012 & 0.0022 & 0.0000 & -0.0217 & 0.2847 & 0.0043 & 1.0000 \\
\hline
\end{tabular}

Notes: BHC total assets enter in log form. The net interest income variable is scaled by BHC average quarterly assets. Trading derivatives (Trading Deriv) includes the sum of the gross notional values of interest rate, foreign exchange, equity and commodity derivatives held for trading scaled by BHC assets. Trading derivative income (Trading Deriv Income) is scaled by the sum of net interest and non-interest income. Real estate loans (R/E loans) are scaled by BHC assets and expressed in first difference. Efficiency is measured as the ratio of bank overhead to the sum of net interest and non-interest income. The GDP\% GAP is the percentage difference between actual and potential GDP and is expressed in first difference. The S\&P500 is the inflation-adjusted returns on the Standard \& Poors 500 index. The TB3MOS is the first difference of the 3-month Treasury bill market rate. Core-Deposits are the first difference of the ratio of core deposits to total BHC liabilities. Core deposits include the sum of non-interest bearing and interest bearing demand deposits, money market and savings accounts plus time deposits $<\$ 100,000$.Non trading derivatives (NonTrading Deriv) include the sum of the gross notional values of interest rate, foreign exchange, equity and commodity derivatives held for purposes other than trading scaled by BHC assets. Dealer is a dummy variable that takes the value of 1 for dealer banks and zero otherwise. Crisis is a dummy variable that takes a value of 1 during the crisis quarters 2007Q3 through 2008Q4 and zero otherwise. 
Table 4. Fixed effects panel models for assessing the impact of trading derivative income on BHC charter value

\begin{tabular}{|c|c|c|c|}
\hline & Model 1 & Model 2 & Model 3 \\
\hline \multicolumn{4}{|l|}{ Independent variables } \\
\hline \multirow[t]{2}{*}{ Constant } & $3.398 * * *$ & $3.360 * * *$ & $3.374 * * *$ \\
\hline & $(0.319)$ & $(0.298)$ & $(0.302)$ \\
\hline \multirow[t]{2}{*}{ BHC Total Assets } & $-0.127 * * *$ & $-0.124 * * *$ & $-0.124 * * *$ \\
\hline & $(0.017)$ & $(0.016)$ & $(0.016)$ \\
\hline \multirow[t]{2}{*}{ Net Interest Income-std } & $0.366^{* *}$ & $0.374 * *$ & $0.362 * *$ \\
\hline & $(0.142)$ & $(0.148)$ & $(0.147)$ \\
\hline \multirow[t]{2}{*}{ Trading Deriv -std } & -0.001 & -0.001 & -0.001 \\
\hline & $(0.001)$ & $(0.001)$ & $(0.001)$ \\
\hline \multirow[t]{2}{*}{ Trading Deriv Income-std } & -0.162 & -0.172 & $-0.542 * * *$ \\
\hline & $(0.103)$ & $(0.109)$ & $(0.134)$ \\
\hline \multirow[t]{2}{*}{$R / E$ loans-std } & 0.274 & 0.276 & 0.278 \\
\hline & $(0.190)$ & $(0.192)$ & $(0.192)$ \\
\hline \multirow[t]{2}{*}{ Efficiency } & -0.057 & -0.057 & -0.055 \\
\hline & $(0.036)$ & $(0.036)$ & $(0.034)$ \\
\hline \multirow[t]{2}{*}{ GDP \% Gap } & $1.617 * * *$ & $1.581 * * *$ & $1.498 * * *$ \\
\hline & $(0.277)$ & $(0.254)$ & $(0.250)$ \\
\hline \multirow[t]{2}{*}{$S \& P 500 \mathrm{ret}$} & -0.020 & -0.026 & -0.023 \\
\hline & $(0.019)$ & $(0.024)$ & $(0.023)$ \\
\hline \multirow[t]{2}{*}{ TB3MO } & -0.012 & $-0.016^{*}$ & $-0.017 * *$ \\
\hline & $(0.007)$ & $(0.008)$ & $(0.008)$ \\
\hline \multirow[t]{2}{*}{ Coredep-std } & $-0.192 *$ & $-0.198 *$ & $-0.182 *$ \\
\hline & $(0.095)$ & $(0.098)$ & $(0.090)$ \\
\hline \multirow[t]{2}{*}{ Non-Trading Deriv -std } & 0.010 & 0.009 & 0.001 \\
\hline & $(0.028)$ & $(0.028)$ & $(0.025)$ \\
\hline \multirow[t]{2}{*}{ Crisis } & & -0.007 & -0.005 \\
\hline & & $(0.009)$ & $(0.008)$ \\
\hline Trading Deriv Income-std* Dealer & & & $\begin{array}{c}0.485^{* * * *} \\
(0.129)\end{array}$ \\
\hline Bank Fixed effects & Yes & Yes & Yes \\
\hline Time dummies & No & No & No \\
\hline Cross sections (BHC) & 27 & 27 & 27 \\
\hline Within $\mathrm{R}^{2}$ & 0.4534 & 0.4543 & 0.4694 \\
\hline
\end{tabular}

Notes: The dependent variable Tobin's Q and all other variables enter the model in quarterly frequency. Refer to Table 3 for a detailed description of the variables employed in the model. We employ Hausman Tests to determine whether fixed or random effects are the appropriate specification. The statistic is Chi-square distributed. The null hypothesis of the test is that the coefficients estimated by random effects estimator are the same as the ones estimated by the fixed effects estimator. Significant P-values support fixed effects estimation. Robust standard errors are reported in parenthesis. The symbols $* * *$ and $* * *$ refer to levels of significance of $10 \%, 5 \%$ and $1 \%$. There are 1063 observations in each model run. Sample Period 2001Q1 -2011Q3. 
Table 5. Charter value quartile and changes in key bank variables

\begin{tabular}{|c|c|c|c|c|}
\hline \multicolumn{5}{|c|}{ Panel A Variable levels at 2008Q4 } \\
\hline $\begin{array}{l}\text { Tobin's Q quartiles } \\
\text { 2006Q4 }\end{array}$ & Tier 1 Cap Ratio & Efficiency & $\begin{array}{l}\text { Trading } \\
\text { Derivatives- } \\
\text { standardized }\end{array}$ & $\begin{array}{l}\text { Trading } \\
\text { Derivative } \\
\text { Income- } \\
\text { standardized }\end{array}$ \\
\hline 1st- lowest & 12.246 & 0.790 & 5.345 & 0.008 \\
\hline 2nd & 10.604 & 0.774 & 5.470 & -0.082 \\
\hline $3 \mathrm{rd}$ & 10.921 & 0.608 & 0.306 & 0.012 \\
\hline 4th-highest & 12.462 & 0.672 & 1.483 & 0.045 \\
\hline Q4-Q1 & 0.216 & -0.118 & -3.861 & 0.037 \\
\hline P-values & 0.910 & 0.461 & 0.489 & 0.425 \\
\hline \multicolumn{5}{|c|}{ Panel B Change in variable between 2006Q4 and 2008Q4 } \\
\hline & Tier 1 Cap Ratio & Efficiency & $\begin{array}{l}\text { Trading } \\
\text { Derivatives- } \\
\text { standardized }\end{array}$ & $\begin{array}{l}\text { Trading } \\
\text { Derivative } \\
\text { Income- } \\
\text { standardized }\end{array}$ \\
\hline 1st- lowest & 2.186 & 0.142 & -1.173 & -0.029 \\
\hline 2nd & 2.158 & 0.190 & 0.755 & -0.110 \\
\hline $3 \mathrm{rd}$ & 0.997 & 0.051 & -0.172 & -0.002 \\
\hline 4th-highest & 2.345 & 0.054 & 0.311 & 0.006 \\
\hline Q4-Q1 & 0.159 & -0.087 & 1.483 & 0.036 \\
\hline P-values & 0.909 & 0.584 & 0.303 & 0.475 \\
\hline
\end{tabular}

Notes: BHC have been divided into quartiles based on 2006Q4 computed Tobin's Q values. For each quartile the mean values of each of the four variables identified above are computed as of 2008Q4 and reported in Panel A. Mean changes in the variables between 2006Q4 and 2008Q4 are computed and reported in Panel B. We test for the differences in means (assuming unequal group variances) between the lowest and highest quartiles. P-values based on two tail test. The null hypothesis is that there is no difference between the means of the two groups. 
Table 6. Robustness checks for fixed effects panel models

\begin{tabular}{|c|c|c|c|}
\hline & Model 1 & Model 2 & Model 3 \\
\hline \multicolumn{4}{|l|}{ Independent variables } \\
\hline Constant & $\begin{array}{c}0.424 * * * \\
(0.055)\end{array}$ & $\begin{array}{c}3.358 * * * \\
(0.298)\end{array}$ & $\begin{array}{l}-0.147 \\
(0.668)\end{array}$ \\
\hline Tobin's $Q$ (1-lag) & $\begin{array}{c}0.897 * * * \\
(0.016)\end{array}$ & & \\
\hline BHC Total Assets & $\begin{array}{c}-0.017 * * * \\
(0.003)\end{array}$ & $\begin{array}{c}-0.125 * * * \\
(0.016)\end{array}$ & $\begin{array}{c}0.048 \\
(0.038)\end{array}$ \\
\hline Net Interest Income-std & $\begin{array}{l}-0.020 \\
(0.057)\end{array}$ & $\begin{array}{c}0.416^{* *} \\
(0.159)\end{array}$ & $\begin{array}{c}0.418^{* *} \\
(0.178)\end{array}$ \\
\hline Trading Deriv -std & $\begin{array}{l}-0.000 \\
(0.000)\end{array}$ & $\begin{array}{l}-0.001 \\
(0.001)\end{array}$ & $\begin{array}{c}0.000 \\
(0.002)\end{array}$ \\
\hline Trading Deriv Income-std & $\begin{array}{l}-0.017 \\
(0.018)\end{array}$ & & $\begin{array}{c}0.885^{* *} \\
(0.367)\end{array}$ \\
\hline Trading Deriv Income-std (1-lag) & & $\begin{array}{l}-0.152 \\
(0.151)\end{array}$ & \\
\hline$R /$ E loans-std & $\begin{array}{l}-0.047 \\
(0.062)\end{array}$ & $\begin{array}{c}0.288 \\
(0.198)\end{array}$ & $\begin{array}{l}-0.107 \\
(0.154)\end{array}$ \\
\hline Efficiency & $\begin{array}{l}-0.002 \\
(0.003)\end{array}$ & $\begin{array}{l}-0.053 \\
(0.033)\end{array}$ & $\begin{array}{c}0.034 \\
(0.029)\end{array}$ \\
\hline GDP \% Gap & $\begin{array}{c}0.330^{* * *} \\
(0.118)\end{array}$ & $\begin{array}{c}1.755^{* * * *} \\
(0.297)\end{array}$ & $\begin{array}{c}0.821^{* *} \\
(0.394)\end{array}$ \\
\hline S\&P 500 ret & $\begin{array}{c}0.072 * * * \\
(0.010)\end{array}$ & $\begin{array}{c}-0.033 \\
(0.026)\end{array}$ & $\begin{array}{l}-0.061 \\
(0.040)\end{array}$ \\
\hline TB3MO & $\begin{array}{c}-0.008^{* *} \\
(0.003)\end{array}$ & $\begin{array}{c}-0.019 * * \\
(0.009)\end{array}$ & $\begin{array}{l}-0.010 \\
(0.015)\end{array}$ \\
\hline Coredep-std & $\begin{array}{c}-0.055^{* *} \\
(0.024)\end{array}$ & $\begin{array}{l}-0.194^{*} \\
(0.098)\end{array}$ & \\
\hline Non-Trading Deriv-std & $\begin{array}{c}0.003 \\
(0.003)\end{array}$ & $\begin{array}{c}0.011 \\
(0.029)\end{array}$ & $\begin{array}{c}-0.094 \\
(0.081)\end{array}$ \\
\hline Crisis & $\begin{array}{c}-0.008 * * * \\
(0.002)\end{array}$ & $\begin{array}{l}-0.004 \\
(0.008)\end{array}$ & $\begin{array}{c}-0.051 * * * \\
(0.017)\end{array}$ \\
\hline Trading Deriv Income-std* Dealer & $\begin{array}{c}0.003 \\
(0.022)\end{array}$ & $\begin{array}{c}0.050 \\
(0.096)\end{array}$ & $\begin{array}{c}-0.985^{* * * *} \\
(0.347)\end{array}$ \\
\hline Bank Fixed effects & Yes & Yes & Yes \\
\hline Time dummies & No & No & No \\
\hline Cross sections (BHC) & 27 & 27 & 27 \\
\hline Within $\mathrm{R}^{2}$ & 0.9316 & 0.4502 & 0.1283 \\
\hline
\end{tabular}

Notes: The dependent variable Tobin's Q in Models 1and 2 is defined as the ratio of the sum of the market value of equity plus the book value of total liabilities to bank holding company (BHC) total assets. The dependent variable in Model 3 is the ratio of core deposits to BHC total deposits. All variables enter the model in quarterly frequency. Refer to Table 3 for a detailed description of the independent variables employed in the models. We employ Hausman Tests to determine whether fixed or random effects are the appropriate specification. The statistic is Chisquare distributed. The null hypothesis of the test is that the coefficients estimated by random effects estimator are the same as the ones estimated by the fixed effects estimator. Significant P-values support fixed effects estimation. Robust standard errors are reported in parenthesis. The symbols *,** and *** refer to levels of significance of $10 \%$, 5\% and 1\%. There are 1063 observations in each model run. Sample Period 2001Q1 -2011Q3. 
Appendix A. List of Sample Bank Holding Companies (BHC).

\begin{tabular}{|c|c|c|c|c|}
\hline Bank Holding Co (BHC) & BCH ID & Ticker Symbol & $\begin{array}{l}\text { Total Assets } \\
9 / 30 / 2011 \\
\text { (dollar } \\
\text { amounts in } \\
\text { thousands) }\end{array}$ & $\begin{array}{l}\text { Total Notional } \\
\text { Value of } \\
\text { Derivatives } \\
\text { 9/30/11 (dollar } \\
\text { amounts in } \\
\text { thousands) }\end{array}$ \\
\hline Wells Fargo \& Co & 1120754 & WFC & $1,304,945,000$ & $3,777,483,000$ \\
\hline US Bancorp & 1119794 & USB & $330,141,000$ & $111,115,000$ \\
\hline SunTrust Banks Inc & 1131787 & STI & $172,583,676$ & $300,898,148$ \\
\hline Capital One Financial Corp & 2277860 & $\mathrm{COF}$ & $200,148,496$ & $72,031,010$ \\
\hline KeyCorp & 1068025 & KEY & $89,405,605$ & $68,803,519$ \\
\hline Commerica Incorporated & 1199844 & CMA & $60,991,256$ & $17,920,010$ \\
\hline First Horizon National Corporation & 1094640 & FHN & $25,572,194$ & $21,950,513$ \\
\hline Citigroup & 1951350 & $\mathrm{C}$ & $1,935,992,000$ & $51,712,103,000$ \\
\hline JP Morgan Chase \& Co & 1039502 & JPM & $2,289,240,000$ & $69,996,484,000$ \\
\hline Associated Banc-Corp & 1199563 & ASBC & $21,902,649$ & $4,304,552$ \\
\hline BB\& T Corporation & 1074156 & BBT & $167,676,889$ & $67,415,207$ \\
\hline BOK Financial Corporation & 1883693 & $\mathrm{BOKF}$ & $24,989,313$ & $32,493,783$ \\
\hline Commerce Bancshares Inc & 1049341 & $\mathrm{CBSH}$ & $20,651,278$ & 644,172 \\
\hline City National Corporation & 1027518 & CYN & $23,104,260$ & $1,859,887$ \\
\hline Bank of America Corporation & 1073757 & BAC & $2,221,386,576$ & $69,785,686,360$ \\
\hline First BanCorp & 2744894 & FBP & $13,475,572$ & 292,871 \\
\hline First Citizens BancShares Inc & 1075612 & FCNCA & $21,015,345$ & 265,933 \\
\hline Fifth Third Bancorp & 1070345 & FITB & $114,904,741$ & $74,345,825$ \\
\hline Huntington Bancshares Inc & 1068191 & HBAN & $54,978,707$ & $24,011,292$ \\
\hline Northern Trust Co & 1199611 & NTRS & $96,098,241$ & $264,816,885$ \\
\hline PNC Financial Services Group Inc & 1069778 & PNC & $269,555,466$ & $372,015,262$ \\
\hline Regions Financial Corp & 3242838 & $\mathrm{RF}$ & $129,761,507$ & $157,966,651$ \\
\hline Synovus Financial Corporation & 1078846 & SNV & $28,253,924$ & $2,055,552$ \\
\hline State Street Corporation & 1111435 & STT & $207,175,585$ & $1,469,172,135$ \\
\hline Zions Bancorporation & 1027004 & ZION & $51,531,600$ & $6,641,391$ \\
\hline TCF Financial Corporation & 2389941 & TCB & $19,120,101$ & 176,541 \\
\hline Popular Inc & 1129382 & BPOP & $38,179,000$ & $1,753,000$ \\
\hline
\end{tabular}




\section{Appendix B. BHC Variables and Code Names}

\begin{tabular}{|c|c|c|c|c|}
\hline \multicolumn{3}{|c|}{ Schedule } & Variable name & Code \\
\hline \multicolumn{3}{|c|}{ HI- Consolidated Income statement } & Net interest income & BHCK 4074 \\
\hline "" & "" & "" & Total noninterest income & BHCK 4079 \\
\hline \multirow[t]{2}{*}{ "" } & "" & "" & Total noninterest expense (bank overhead) & BHCK 4093 \\
\hline & & & Trading Revenue & BHCK A220 \\
\hline \multicolumn{3}{|c|}{ HC-Consolidated Balance Sheet } & Total assets & BHCK 2170 \\
\hline "" & "" & "" & Total liabilities & BHCK 2948 \\
\hline \multicolumn{3}{|c|}{ HC- C- Loans \& Leases Financing Receivables } & Loans secured by real estate & BHCK 1410 \\
\hline "" & "" & "" & Total loans & BHCK 2122 \\
\hline \multicolumn{3}{|c|}{ HC- E- Deposit Liabilities } & Interest bearing demand deposits & BHCB 3187 \\
\hline "" & "" & "" & Non-interest bearing deposits & BHCB 2210 \\
\hline "" & "" & "" & MMD \& other savings accounts & BHCB 2389 \\
\hline "" & "" & "" & Time deposits $<\$ 100,000$ & ВНСB 6648 \\
\hline \multicolumn{3}{|c|}{ HC-K- Quarterly Averages } & Total assets & BHCK 3368 \\
\hline \multicolumn{3}{|c|}{ HC- L- Derivatives and Off Balance Sheet Items } & Gross notional interest rate derivatives held for trading & BHCKA126 \\
\hline "" & "" & "" & Gross notional foreign exchange derivatives held for trading & BHCKA127 \\
\hline "" & "" & "" & Gross notional equity derivatives held for trading & BHCK 8723 \\
\hline "" & "" & "" & Gross notional commodity derivatives held for trading & BHCK 8724 \\
\hline "" & "" & "" & Gross notional interest rate derivatives non-trading & BHCK 8725 \\
\hline "" & "" & $" "$ & Gross notional foreign exchange derivatives non-trading & BHCK 8726 \\
\hline "" & "" & "" & Gross notional equity derivatives non-trading & BHCK 8727 \\
\hline "" & "" & "" & Gross notional commodity derivatives non-trading & BHCK 8728 \\
\hline & ulat & & Tier 1 risk based capital ratio & BHCK 7206 \\
\hline
\end{tabular}

Source: Federal Reserve Bank of Chicago website https://www.chicagofed.org/applications/bhc_data/bhcdata_index.cfm last accessed on 9/20/12. 